\title{
WHAT HAPPENS WHEN BOOKS ENTER THE PUBLIC DOMAIN? TESTING COPYRIGHT'S UNDERUSE HYPOTHESIS ACROSS AUSTRALIA, NEW ZEALAND, THE UNITED STATES AND CANADA
}

JACOB FLYNN, REBECCA GIBLIN AND FRANÇOIS PETITJEAN*

\section{Accepted for publication in the University of New South Wales Law Journal, Issue 42(4), November 2019.}

This is a preprint. The published paper may contain changes after editorial revision.

\footnotetext{
Mr Jacob Flynn is a Bachelor of Laws (Hons) \& Bachelor of Science student, Monash University, Australia. Dr Rebecca Giblin is an ARC Future Fellow, CREATe Fellow and Associate Professor, Faculty of Law, Monash University. Dr François Petitjean is an ARC DECRA Fellow and Senior Research Fellow, Faculty of Information Technology, Monash University. This research was partially funded by the Australian Research Council via projects LP160100387, FT170100011 and DE170100037. It also received funding support from Monash University. The authors thank Professors Imke Reimers and Paul J Heald who reviewed an earlier draft of the paper, and the three anonymous reviewers who considered it for publication; the thoughtful comments and feedback of each valuably strengthened the paper.
} 


\section{INTRODUCTION}

Worldwide, copyright laws are routinely criticised for failing to satisfy two of their most fundamental aims: promoting widespread access to knowledge and culture, and rewarding authors. ${ }^{1}$ One of the most significant reform initiatives of recent decades has been to extend the duration of rights - a change that has been argued would improve outcomes for both. ${ }^{2}$ The Berne Convention mandates a minimum term, for most works, of the author's lifetime + a further 50 years. ${ }^{3}$ The European Economic Community extended this to life +70 in $1993^{4}$ and the United States ('US') promptly followed suit. ${ }^{5}$ Since then, it has doggedly exported the extension to other nations via 'free trade' agreements. ${ }^{6}$ Australia adopted the extended term as part of its obligations under the Australia-US Free Trade Agreement in 2005. ${ }^{7}$ Canada recently committed to the longer term too, as part of the United StatesMexico-Canada Agreement that replaces NAFTA. ${ }^{8}$

1 For fuller discussion of the rationales and justifications for copyright, see below Part II.

2 See, eg, Senate Committee on the Judiciary, 'Copyright Term Extension Act of 1996' (Report No 104-315, 10 July 1996) 3, justifying the 1998 United States ('US') term extension on the grounds that it would 'ensur[e] fair compensation for American creators who deserve to benefit fully from the exploitation of their works' and 'provid[e] enhanced economic incentives to preserve existing works'.

3 Berne Convention for the Protection of Literary and Artistic Works, opened for signature 9 September 1886, 828 UNTS 221 (entered into force 5 December 1887) art 7(1) ('Berne Convention'). This is a minimum term only and parties may adopt longer terms: at art 7(6). This obligation also accrues to nations party to the Marrakesh Agreement Establishing the World Trade Organization, opened for signature 15 April 1994, 1867 UNTS 3 (entered into force 1 January 1995) annex IC ('Agreement on Trade-Related Aspects of Intellectual Property Rights'): at art 9(1).

4 Council Directive 93/98/EEC of 29 October 1993 Harmonizing the Term of Protection of Copyright and Certain Related Rights [1993] OJ L 290/9, art 1(1).

5 Sonny Bono Copyright Term Extension Act, Pub L No 105-298, § 102b, 112 Stat 2827, 2827-8 (1998) ('Copyright Term Extension Act'), amending 17 USC § 302 (2012).

6 See, eg, Australia-United States Free Trade Agreement, signed 18 May 2004, [2005] ATS 1 (entered into force 1 January 2005) art 17.4(4) ('Australia-US Free Trade Agreement'); Free Trade Agreement between the United States of America and the Republic of Korea, signed 30 June 2007 (entered into force 15 March 2012) art 18.4(4); United States-Mexico-Canada Agreement art 20.H.7, which will replace the North American Free Trade Agreement, CanadaMexico-United States of America, signed 17 December 1992, 32 ILM 289 (entered into force 1 January 1994) ('NAFTA'). The United States-Mexico-Canada Agreement was signed on 30 November 2018 but is yet to be ratified: 'United States-Mexico-Canada Agreement', Office of the United States Trade Representative (Web Page) <ustr.gov/trade-agreements/free-tradeagreements/united-states-mexico-canada-agreement>.

7 US Free Trade Agreement Implementation Act 2004 (Cth) sch 9 item 120 ('AUSFTA Implementation Act'), amending Copyright Act 1968 (Cth) s 33(2) ('Copyright Act').

8 Alex Boutilier, 'Canada Capitulates on Copyright in New USMCA Deal, Experts Say', The Star (online, 1 October 2018) <thestar.com/news/canada/2018/10/01/canada-capitulates-oncopyright-in-new-usmca-deal.html>. The United States-Mexico-Canada Agreement is not yet in force. However, its terms have been agreed upon. Under art 20.H.7(a), copyright terms calculated on the basis of the life of a natural person must be no less than life plus 70. A draft of the agreement is available at 'United States-Mexico-Canada Agreement' (n 6). 
Claims that these extended terms would further copyright's core aims have been vigorously critiqued. ${ }^{9}$ Claims that copyright extensions financially benefit authors are particularly weak. An extension that kicks in half a century after an author dies obviously cannot provide them with any additional rewards - or encourage them to make a single new work. In any event, the additional years of economic rights almost always vest, not in works' authors, but their owners and licensees. ${ }^{10}$ Thus, the lion's share of any benefit flows to corporate investors, such as publishers and record labels, rather than creators themselves. It has been argued that those corporations would invest the resulting windfall profits into the creation of additional new works that could not otherwise have been funded. But that has been criticised, including by a team of Nobel Prize-winning economists, for assuming that investors have a lack of access to capital markets and are willing to invest in sub-par projects. ${ }^{11}$ This leaves one key economic argument justifying retroactive grants of additional protection: that exclusive rights are necessary to persuade publishers to continue to invest in making older works available — and that, otherwise, they will be underused. ${ }^{12}$

This paper investigates that 'underuse hypothesis' ${ }^{13}$ Not all copyright theories are capable of rigorous assessment, but the underuse claim is a testable hypothesis 'ripe for empirical analysis'. ${ }^{14}$ As developed below, it has previously been the subject of a handful of published studies, but never outside the US context and never by comparing the availability of identical works across jurisdictions with different copyright terms. ${ }^{15}$ This study does both, comparing the relative availability of

9 These critiques are canvassed in detail in Rebecca Giblin, 'Reimagining Copyright's Duration' in Rebecca Giblin and Kimberlee Weatherall (eds), What if We Could Reimagine Copyright? (Australian National University Press, 2017) 177, 179-96.

10 There is a narrow exception to this under US law: the Copyright Term Extension Act (n 5) gave authors and their heirs a termination right 75 years from first publication, but only if they had not exercised their prior termination right at the end of 56 years from first publication. See 17 USC $\S 304(c)-(d)$ (2012).

11 George A Akerlof et al, 'Brief of George A Akerlof, Kenneth J Arrow, Timothy F Bresnahan, James M Buchanan, Ronald H Coase, Linda R Cohen, Milton Friedman, Jerry R Green, Robert W Hahn, Thomas W Hazlett, C Scott Hemphill, Robert E Litan, Roger G Noll, Richard Schmalensee, Steven Shavell, Hal R Varian and Richard J Zeckhauser as Amici Curiae in Support of Petitioners', Submission in Eldred v Ashcroft, No 01-618, 20 May 2002, 9. Cf Stan J Liebowitz and Stephen Margolis, 'Seventeen Famous Economists Weigh in on Copyright: The Role of Theory, Empirics and Network Effects' (2005) 18(2) Harvard Journal of Law and Technology 435, questioning the assumptions in that brief.

12 See below Part II(B).

13 Christopher Buccafusco and Paul J Heald, 'Do Bad Things Happen When Works Enter the Public Domain?: Empirical Tests of Copyright Term Extension' (2013) 28(1) Berkeley Technology Law Journal 1, 13.

14 Paul J Heald, 'Does the Song Remain the Same? An Empirical Study of Bestselling Musical Compositions (1913-1932) and Their Use in Cinema (1968-2007)' (2009) 60(1) Case Western Law Review 1, 4 ('Does the Song Remain the Same?').

15 Having said that, our literature review was limited to the English language and it is possible that there are further studies published in other languages and not referenced in the English language literature which we have not been able to identify. We also note the existence of a small unpublished study examining the availability of Miles Franklin Literary Award-winning novels in Australia (in print and digitally): 'How Copyright Makes Australian Books Disappear', Greg Tangey (Blog Post, 29 September 2013) <gregtangey.wordpress.com/2013/09/29/howcopyright-makes-australian-books-disappear/>. 
ebooks to public libraries across Australia, New Zealand ('NZ'), the US and Canada, to evaluate whether the underuse hypothesis is working as promised.

Part II explains the underuse hypothesis in more detail and briefly reviews the literature to have tested it so far. Part III describes our research questions and methods for addressing them. Part IV sets out our results. We find that books are actually less available where they are under copyright than where they are in the public domain, and that commercial publishers seem undeterred from investing in works even where others are competing to supply the same titles. We also find that exclusive rights do not appear to trigger investment in works that have low commercial demand, with books from $59 \%$ of the 'culturally valuable' authors we sampled unavailable in any jurisdiction, regardless of copyright status. Further, we find that works are priced much higher where they are under copyright than where they in the public domain, and these differences typically far exceed what would be paid to authors or their heirs. Part V concludes with observations about the implications of these results for future term extension. We argue that, where lengthier rights must be awarded, countries ought to pay much more careful attention to the way they are divided up in order to better achieve copyright's aims while limiting undesired collateral damage.

\section{THE UNDERUSE HYPOTHESIS}

\section{A Situating the Underuse Hypothesis within the Rationales for Copyright}

A rich tapestry of rationales have been advanced to justify copyright, including that it enhances democratic civil society and operates as protection against unfair competition. ${ }^{16}$ But above all others sit the two most fundamental: the 'utilitarian' and 'natural rights' rationales. Utilitarian theories justify copyright as a way of securing particular economic and social aims, such as the benefits that come from widespread access to knowledge and culture. Prioritising the interests of the broader public, utilitarian theories justify the grant of exclusive rights in order to incentivise investments in information and culture, whilst seeking to minimise the social welfare costs that come from doing so. ${ }^{17}$ A purely utilitarian approach would provide the bare minimum necessary to incentivise the desired investments.

The second rationale is grounded in natural rights. Natural rights theories posit that copyright is awarded because it is just and right to do so, typically because they have sprung from the author's labour (per Locke), or because they represent a materialisation of her personality (per Kant and Hegel). In naturalist framings, it's the 'indissoluble personal link' between creator and work that gives rise to rights,

16 See, eg, Neil Weinstock Netanel, 'Copyright and a Democratic Civil Society' (1996) 106(2) Yale Law Journal 283; Mark J Davison, Ann L Monotti and Leanne Wiseman, Australian Intellectual Property Law (Cambridge University Press, $2^{\text {nd }}$ ed, 2012) 4-5.

17 Peter Drahos and John Braithwaite, Information Feudalism (Earthscan, 2002) 176. 
and that justifies broader protection than the bare minimum incentive that would have elicited the work. ${ }^{18}$

Today these theories are given different weight in different parts of the world. Utilitarian theories are espoused particularly strongly by British Commonwealth countries and their former colonies, including the US. Continental European countries such as France and Germany (and their former colonies too) are the ones most strongly driven by natural rights considerations. However, the copyright laws of every jurisdiction contain elements attributable to both consequentialist and deontological rationales. ${ }^{19}$

This paper is primarily concerned with testing the utilitarian rationales for copyright. Insofar as they justify the grant of copyright, it's as an incentive in order to achieve broader aims. Two primary incentives have been identified as necessary. First, copyright is supposed to incentivise works' initial creation, together with whatever investments are necessary to get them to market and available to the public. Second, it's supposed to incentivise investments in those works' ongoing availability. After all, society will stop benefiting from works when they can no longer be accessed. As developed further below, it is these investments in ongoing availability that the underuse hypothesis is concerned with.

\section{B A Closer Look at the Underuse Hypothesis}

At the centre of the underuse hypothesis is the argument that, unless investors are guaranteed additional exclusive rights (above and beyond what was necessary to incentivise a work's initial creation), they will not invest in activities necessary to ensuring works' ongoing availability, and culture will languish, unexploited.

The underuse hypothesis is a variation on the well-known 'free-rider problem' ${ }^{20}$ If people can benefit from a creative or informational work without contributing to the costs of creating it, the theory goes, they will 'free ride' on the result. Then nobody will have an incentive to contribute to those initial costs, and many works simply will not be created. ${ }^{21}$ Intellectual property is particularly vulnerable to free-

18 Ibid.

19 See, eg, Martin Senftleben, Copyright, Limitations and the Three-Step Test: An Analysis of the Three-Step Test in International and EC Copyright Law (Kluwer Law, 2004) 6-10. Ginsburg's historical analysis demonstrates how even the US, which professes such a strong utilitarian tradition, has been influenced by 'authors"' claims of personal right: Jane C Ginsburg, 'A Tale of Two Copyrights: Literary Property in Revolutionary France and America' (1990) 64(5) Tulane Law Review 991, 995. See also Alain Strowel, Droit d'auteur et copyright: Divergences et convergences (Bruylant, 1993); Gillian Davies, Copyright and the Public Interest (Sweet \& Maxwell, $2^{\text {nd }}$ ed, 2002) 348-51; JH Reichman, 'Duration of Copyright and the Limits of Cultural Policy' (1996) 14(3) Cardozo Arts \& Entertainment Law Journal 625, 643-4; Sam Ricketson, 'The Copyright Term' (1992) 23(6) International Review of Industrial Property and Copyright Law 753, 755; Alfred C Yen, 'Restoring the National Law: Copyright as Labor and Possession' (1990) 51(2) Ohio State Law Journal 517.

20 Buccafusco and Heald (n 13) 13.

21 Ibid. 
riding, since it 'is expensive to create' but 'cheaply copied'. ${ }^{22}$ If we extend this reasoning beyond the creation of works, and to their maintenance and distribution, we arrive at the underuse hypothesis. ${ }^{23}$ As Landes and Posner argue, 'an absence of copyright protection for intangible works may lead to inefficiencies because of ... impaired incentives to invest in maintaining and exploiting these works' ${ }^{24}$ In other words, publishers are less likely to risk investing in works unless they hold the exclusive rights to do so.

Exclusive rights are available for as long as a work is restricted by copyright, but not once it enters the public domain. At this point, it has been argued, the free rider problem rears its head. If anyone can freely copy public domain works, that interferes with publishers' incentives to make them available, and society will have less access.

The underuse hypothesis played a key role in 1990s debates about whether the US should extend its copyright term. It was by no means the main impetus or justification for the proposed extension: the prime driver was clearly the European Union's recent adoption of a life +70 year term. ${ }^{25}$ That had generated an additional 20 years of exclusive rights which would not be enjoyed by the owners of American works unless the US extended its own term to match. ${ }^{26}$ But the proposed US extension was strenuously opposed on the basis of the harm it would cause to the public domain, and the underuse hypothesis played a key supporting role in counteracting those claims. By making the case that public domain works are less available than those still under copyright, it weakened the opposition's claims about the public domain's economic and social value, changed the cost-benefit calculus, and strengthened the case for extension.

We can see numerous examples of this use of the underuse hypothesis in the evidence provided to Congress. For example, the Register of Copyrights testified that a 'lack of copyright protection ... restrains dissemination of the work, since publishers and other users cannot risk investing in the work unless assured of exclusive rights'. ${ }^{27}$ The Coalition of Creators and Copyright Owners similarly argued that 'works protected by copyright are far more likely to be made widely available to the public in a form the public wants to enjoy than works in the public

22 Ibid.

23 Ibid 13-14.

24 William M Landes and Richard A Posner, 'Indefinitely Renewable Copyright' (2003) 70(2) University of Chicago Law Review 471, 475.

25 See, eg, Senate Committee on the Judiciary (n 2) 12-13; House of Representatives Committee on the Judiciary, 'Copyright Term Extension Act' (Report No 105-452, 18 March 1998) 4.

26 Under the Berne Convention (n 3), copyright term is governed by the country in which protection is claimed. However, unless that country so decides, it won't exceed the term fixed in the work's country of origin: at art 7(8).

27 Evidence to Subcommittee on Courts and Intellectual Property of the Committee on the Judiciary, House of Representatives, Washington, 13 July 1995, 188 (Marybeth Peters, Register of Copyrights). 
domain'. ${ }^{28}$ The Commissioner of Patents and Trademarks acknowledged that the opposition to term extension was focused around the public harm it would cause, but testified there was 'ample evidence [showing] that once a work falls into the public domain it is neither cheaper nor more widely available than works protected by copyright'. ${ }^{29}$ Notably, although this part of his testimony was provided by way of a written submission, the Commissioner did not provide any examples or citations evidencing this claim. In his oral testimony, he did refer to 'some evidence ... that the restoration of copyright protection under the NAFTA legislation actually encouraged industry to make available to the public in new editions, and much finer editions, works which otherwise would have remained mouldering in the library' ${ }^{30}$ But here also he failed to provide any source that would enable this evidence to be identified and examined.

The underuse hypothesis is notably at odds with classical economic theory, of which a core tenet is that investors will continue to produce copies 'up to the point where the marginal cost of one more copy equals its expected marginal revenue'. ${ }^{31}$ In other words, economic theory posits that publishers should rationally continue producing copies of books (or anything else) so long as they can expect to get back more than they put in. Lemley captures the tension between the two theories:

It is hard to imagine senators, lobbyists, and scholars, arguing with a straight face that the government should grant one company the perpetual right to control the sale of all paper clips in the country on the theory that otherwise no one will have an incentive to make and distribute paper clips. We know from long experience that companies will make and distribute paper clips if they can sell them for more than it costs to supply them. ... We can also predict with some confidence that if we did grant one company the exclusive right to make paper clips, the likely result would be an increase in the price and a decrease in the supply of paper clips. Yet supporters of [copyright term extensions] confidently predict exactly the opposite in the case of copyrighted works ... ${ }^{32}$

Despite this clash (and the lack of evidence that the underuse theory works in practice) it received support from both the US legislative and judicial branches. The

28 Evidence to Subcommittee on Courts and Intellectual Property of the Committee on the Judiciary, House of Representatives, Washington, 13 July 1995, 633-4 (Coalition of Creators and Copyright Owners).

29 Evidence to Subcommittee on Courts and Intellectual Property of the Committee on the Judiciary, House of Representatives, Washington, 13 July 1995, 217-18 (Bruce A Lehman, Commissioner of Patents and Trademarks). The Commissioner went on to add that '[o]ne reason quality copies of public domain works are not as widely available may be because publishers will not publish a work that is in the public domain for fear that they will not be able to recoup their investment or earn enough of a profit': at 218.

30 Evidence to Subcommittee on Courts and Intellectual Property of the Committee on the Judiciary, House of Representatives, Washington, 13 July 1995, 212 (Bruce A Lehman, Commissioner of Patents and Trademarks).

31 William M Landes and Richard A Posner, 'An Economic Analysis of Copyright Law' (1989) 18(2) Journal of Legal Studies 325, 327.

32 Mark A Lemley, 'Ex Ante Versus Ex Post Justifications for Intellectual Property’ (2004) 71(1) University of Chicago Law Review 129, 135-6 (citations omitted). 
House of Representatives report recommending the extension stated, among other reasons, that it 'would provide copyright owners generally with the incentive to restore older works and further disseminate them to the public'. ${ }^{33}$ The US Supreme Court, upholding that extension's constitutionality, observed that Congress had 'rationally credited projections that longer terms would encourage copyright holders to invest in ... public distribution of their works'. ${ }^{34}$ The underuse hypothesis was also widely recognised in academic literature developed around this same time. ${ }^{35}$ Thus, although the underuse hypothesis was not the prime driver behind the US term extension, it clearly played a key supporting role in justifying the extension and counteracting opposition. Given the stakes at play, it is crucial to understand the extent to which it is supported by real-world practice.

\section{Previous Tests of the Underuse Hypothesis}

The 20 years since the US term extension were passed have seen enormous increases in the amount and quality of empirical evidence relevant to copyright law and policy. ${ }^{36}$ In that time, six key studies have tested the underuse hypothesis. As developed below, one working paper examining the 19th century US book market reports evidence of publisher reluctance to invest in printing books where they did not have exclusive rights, but each of the five published studies based on more recent data finds the opposite: that works restricted by copyright are actually subject to less investment and narrower dissemination than their counterparts in the public domain.

\section{Physical Books}

(a) Khan (2004)

The best evidence in support of the underuse hypothesis comes from a working paper examining publisher behaviour in the US before 1920, when its law did not yet recognise copyright in foreign books. ${ }^{37}$ The study found evidence that, at that time, publishers were wary of publishing foreign works. Their concern was that others could then inexpensively copy their edition and offer it at a lower price,

33 House of Representatives Committee on the Judiciary, 'Copyright Term Extension Act' (n 25) 4.

34 Eldred v Ashcroft, 537 US 186, 207 (Ginsburg J for Rehnquist CJ, Ginsburg, O’Connor, Scalia, Kennedy, Souter and Thomas JJ) (2003) ('Eldred').

35 See eg Arthur R Miller, 'Copyright Term Extension: Boon for American Creators and the American Economy' (1998) 45(3) Journal of the Copyright Society of the USA 319, 324; Symposium, 'The Constitutionality of Copyright Term Extension: How Long is Too Long?' (2000) 18(3) Cardozo Arts and Entertainment Law Journal 651, 692-3; Orrin G Hatch and Thomas R Lee, “To Promote the Progress of Science": The Copyright Clause and Congress's Power to Extend Copyrights' (2002) 16(1) Harvard Journal of Law and Technology 1, 16-20; Landes and Posner, 'Indefinitely Renewable Copyright' (n 24) 475. Cf the alternative (contradictory) hypothesis that a lack of copyright may actually result in overuse of works: at 485-8.

36 See Copyright Evidence (Web Page, 5 March 2018) <copyrightevidence.org>.

37 B Zorina Khan, 'Does Copyright Piracy Pay? The Effects of US International Copyright Laws on the Market for Books, 1790-1920' (Working Paper No 10271, National Bureau of Economic Research, January 2004). 
driving the price down and potentially preventing them from recouping their initial investment. ${ }^{38}$ The publishing industry solved the problem internally — by colluding to informally allow one another exclusivity over particular books. ${ }^{39}$

(b) Heald (2008)

In 2008, Heald studied the availability of bestselling novels published in the US between 1913-32. ${ }^{40}$ Heald sampled 352 books, predominantly from yearly bestseller lists. ${ }^{41}$ Of these, 166 were published pre-1923 and therefore in the US public domain, ${ }^{42}$ while the remaining 186 were published post-1923 and remained under copyright. ${ }^{43}$ Within each group, the 20 'most currently popular' books were also identified to create a 'durable books' subgroup. ${ }^{44}$

Heald then compared the books' availability. As of 2006, he found that public domain books were generally available at higher rates than books under copyright ( $98 \%$ compared to $74 \%$ ), though both durable books subgroups were fully available $(100 \%) .{ }^{45}$ Public domain books were also available in more editions on average than books under copyright (5.2 editions compared to 3.2$).{ }^{46}$ For the durable books subgroups, the difference was more dramatic still: public domain durable books were available in an average of 29.1 editions, while their equivalents under copyright averaged $8.9 .{ }^{47}$

Pricing was similar for copyright and public domain books, with the average lowest price for each group found to be identical. ${ }^{48}$ However, for the durable books subgroups, the average lowest price of the copyright titles was $81 \%$ higher than that of their counterparts in the public domain. ${ }^{49}$

Heald concluded that, contrary to the underuse hypothesis, public domain books were not less available than copyright books. ${ }^{50}$ Instead, the data evidenced 'a highly

\footnotetext{
38 Ibid 21.

39 Ibid 25.

40 Paul J Heald, 'Property Rights and the Efficient Exploitation of Copyrighted Works: An Empirical Analysis of Public Domain and Copyrighted Fiction Best Sellers' (2008) 92(4) Minnesota Law Review 1031 ('Property Rights and the Efficient Exploitation of Copyrighted Works').

41 Ibid 1037.

42 On the reason that works published before 1923 are in the public domain in the US, see below $\mathrm{n}$ 98.

43 Heald, 'Property Rights and the Efficient Exploitation of Copyrighted Works' (n 40) 1039.

44 Ibid 1038-9.

45 Ibid 1040, 1044.

46 Ibid 1043.

47 Ibid 1045.

48 Ibid 1043.

49 Ibid 1048.

50 Ibid 1053.
} 
competitive and robust market' supporting production of titles in the public domain. ${ }^{51}$

(c) Heald (2014)

Six years later, Heald released a further study, this time examining the availability of books for sale via online retailer Amazon. ${ }^{52}$ He randomly sampled 7000 titles and estimated the publication date of each based on Library of Congress records. ${ }^{53}$ This yielded 2266 unique fiction books: ${ }^{54} 72 \%$ in the public domain and $28 \%$ still under copyright. ${ }^{55}$ The sample ended up containing a large proportion of books from the 1850 s to 1920 s, very few from the 1930 s to 1980 s, and a higher proportion again from the 1990s and 2000s ${ }^{56}$ It contained just 38 books from the 1880 s and only 25 from the 1980s, despite the fact that seven times as many books were published in the latter period than in the former. ${ }^{57}$

These results were consistent with Heald's earlier finding that pre-1923 public domain books were more widely available than post-1923 books that were still under copyright. Based on this data, Heald proposed that books are made widely available when first published, soon 'disappear' due to copyright protection (and other factors such as age), ${ }^{58}$ and eventually 'reappear' upon entering the public domain. ${ }^{59}$

\section{Recorded Music}

(a) Brooks (2005)

The underuse hypothesis has also been tested in the context of sound recordings. In 2005, Brooks investigated the current availability of sound recordings that had been commercially released in the US between 1890 and $1964 .{ }^{60}$ Based on a random sample of 1500 recordings, he found that just $14 \%$ had been reissued on CD by copyright holders. ${ }^{61}$ By contrast, $22 \%$ had been reissued exclusively by non-rights holders such as foreign labels and 'small domestic operations operating under the legal radar'. ${ }^{62}$ This suggested that exclusive publication rights were not necessary

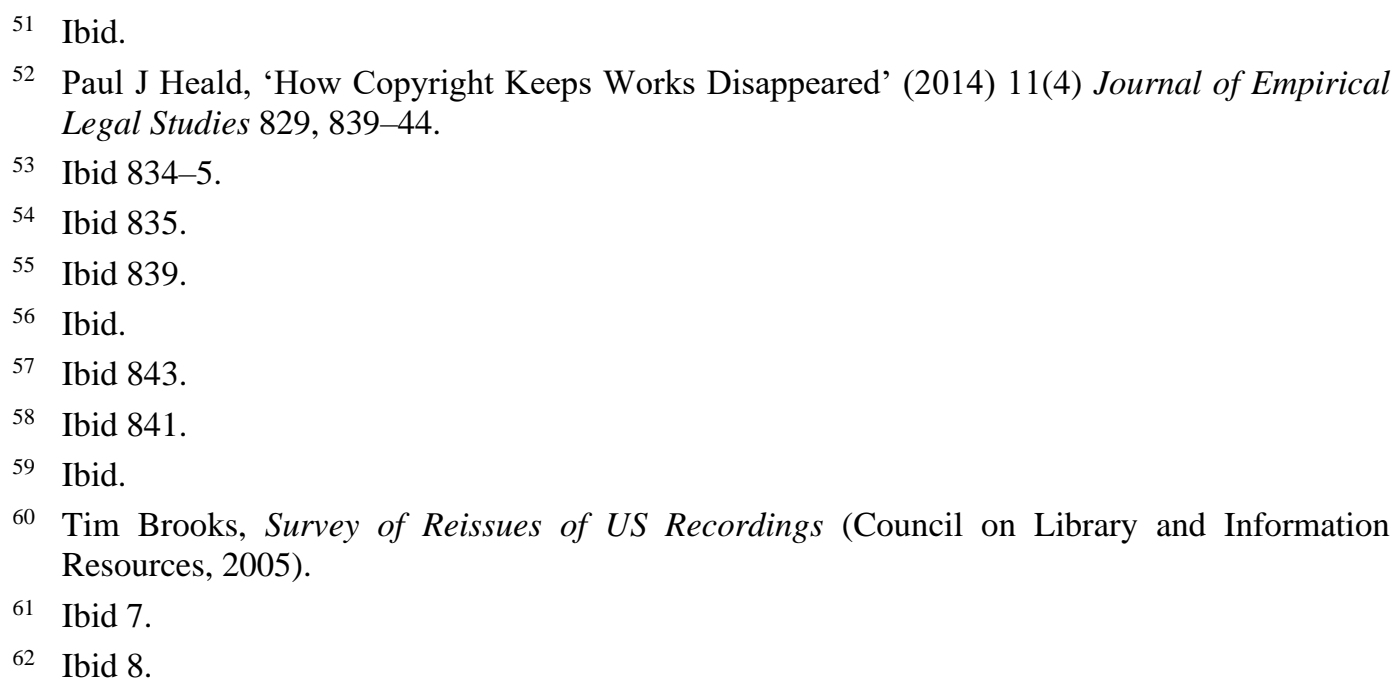


to incentivise investment in making sound recordings available, and actually got in the way of others seeking to do so. ${ }^{63}$

(b) Heald (2009) and Heald (2014)

Also in the context of music, Heald has empirically shown that public domain musical compositions are not less likely than copyright compositions to be included in new release films, ${ }^{64}$ and in fact more likely to be included on DVD releases. ${ }^{65}$

\section{Audiobooks}

(a) Buccafusco and Heald (2013)

In 2013, Buccafusco and Heald studied the availability of audiobook recordings of popular novels. ${ }^{66}$ Unlike the other studies discussed above, this was not an analysis of the availability of copyright-restricted and public domain works in and of themselves, but rather works derived from pre-existing works ('derivative works'). Adopting a similar methodology to Heald's 2008 study, Buccafusco and Heald sampled 171 public domain books and 174 books under copyright. ${ }^{67}$ Again, subgroups of durable books were also identified. ${ }^{68}$

Buccafusco and Heald then searched popular online retailers for audiobook recordings of these books and compared availability and pricing. ${ }^{69}$ They found that public domain books were more than twice as likely as copyright books to be available as audiobook recordings. Only $16 \%$ of the copyright books had at least one audiobook recording available, compared with $33 \%$ of the public domain books. ${ }^{70}$ For the durable books subgroups, the rates were $80 \%$ and $100 \%$ respectively. ${ }^{71}$

They further found that, among books available as audiobooks, public domain titles were available in marginally more audiobook editions than were the books under copyright. Copyright books averaged 3.0 recordings per book, compared to 3.3 for titles in the public domain. ${ }^{72}$ For the durable books subgroups, the difference was more substantial, at 3.25 compared with 6.25 editions, again in favour of the public domain. ${ }^{73}$

63 Though note Heald has found that music publishers more recently appear to be doing a better job of making old songs available online: Heald, 'How Copyright Keeps Works Disappeared' (n 53) $856-8$.

64 Heald, 'Does the Song Remain the Same?' (n 14) 12.

65 Heald, 'How Copyright Keeps Works Disappeared' (n 53) 848-9.

66 Buccafusco and Heald (n 13).

67 Ibid 21.

68 Ibid.

69 Ibid 21-2.

70 Ibid 22.

71 Ibid 23.

72 Ibid 22.

73 Ibid 23. 
Pricing of the two groups was similar - CD recordings averaged US\$28 for copyright books and US $\$ 26$ for public domain books, and $\mathrm{mp} 3$ downloads averaged US\$19 and US\$22 respectively. ${ }^{74}$ For the durable books subgroups, the difference was again more material. The average per minute cost for $C D$ recordings was US $\$ 0.050$ for copyright books and US $\$ 0.038$ for public domain books. For mp3 recordings, the cost was US $\$ 0.036$ for copyright books and US $\$ 0.028$ for those in the public domain. ${ }^{75}$

The study concluded that public domain status does not reduce availability, but in fact seems to increase it. ${ }^{76}$ Despite the relatively high cost of producing audiobooks, a far more expensive process than producing physical copies or ebooks, '[p]roducers ... are clearly not deterred by their inability to exclude competitors from making competing products. ... A right to exclude is clearly not needed to incentivize the production of audiobooks made from older works' ${ }^{77}$

\section{What Do These Analyses Tell Us?}

The one empirical support for the underuse hypothesis comes from Zhan's working paper, which linked publisher unwillingness to invest in publishing foreign works to a lack of exclusive rights. However, each of the other five studies to have tested the hypothesis has reached the opposite result.

Heald has argued that the high fixed costs associated with $19^{\text {th }}$ century book production may have been what drove publishers' reluctance to 'race' each other to get books to market. ${ }^{78}$ If that is correct, we could expect competition to be less of a deterrent to investment as production costs decrease. Interestingly however, Heald and Buccafusco themselves subsequently found no support for the underuse hypothesis in the case of relatively expensive audiobook production, suggesting there must be more to the story. We can at least say that the empirical evidence base to date casts significant doubt on the underuse hypothesis, particularly in cases where fixed costs of production are relatively low.

\section{This Study's Contribution to the Literature}

Notably, each of the above studies focuses on the relative availability of copyright and public domain works in a single jurisdiction, the US. ${ }^{79}$ Our study tests the underuse hypothesis for the first time across not only the US, but also Australia, $\mathrm{NZ}$ and Canada.

\footnotetext{
74 Ibid 22.

75 Ibid 23.

76 Ibid 29.

77 Ibid 30.

78 Heald, 'Property Rights and the Efficient Exploitation of Copyrighted Works' (n 40) 1035-6.

79 Although Brooks (n 61) counted reissues available from foreign entities, he did not specify their locations.
} 
Comparing availability across these jurisdictions is of particular interest because of differences in the way copyright terms are determined in each. Before 1978, the US relied upon a copyright renewal system. Works were protected for an initial term, and then granted a second term if the copyright owner opted to proceed with an administrative process to renew them. ${ }^{80}$ Renewal rates were low, and copyrights were more likely to be renewed for the more valuable and popular works. ${ }^{81}$ That system can skew the analysis, because the most valuable works are likely to enter the public domain later than less popular ones that had been created at the same time. For example, comparisons of pre-1923 and post-1923 samples in the US are affected by the fact that, while all pre-1923 works were in the public domain, only the more valuable and popular of the post-1923 works were likely to be still under copyright. By contrast, copyright status in Australia, NZ and Canada over the relevant period has been determined solely by fixed copyright terms, with the consequence that there are no term differences between more and less valuable works of the same age.

Because our study examines ebooks, rather than physical books, it also usefully enables us to gauge the willingness of publishers to make non-trivial investments in public domain works. While ebooks are less expensive to produce than ever before, they still require investments in scanning, formatting and proofreading in order to derive a saleable ebook from the original physical form. Thus, the results we obtain add to the work of Heald and Buccafusco in understanding how copyright status correlates with publisher willingness to invest in new works derived from the originals.

Our study is also the first to test the underuse hypothesis via a title-level analysis - ie by examining the relative availability of the same works across multiple jurisdictions where their copyright status differed. The intra-US studies described above obviously could not do that, because a given work can only have one copyright status in a single jurisdiction. This method may open up new possibilities for evaluating the costs or benefits associated with term extension.

\section{METHODS}

In this paper we test the underuse hypothesis in the context of the library elending market. If the hypothesis is correct, we should see that commercial publishers invest less in making public domain books (for which they don't have exclusive rights) available than books that are still under copyright. In this section we first explain the library elending ecosystem, then briefly describe how we constructed our sample, collected and cleaned our data, and matched titles to enable crossjurisdiction comparison. We then set out the questions we used to test the hypothesis.

80 Renewal became automatic for works published on or after 1 January 1964 and was abolished altogether from 1 January 1978. Regarding the US approach to term, see generally Robert Brauneis, 'A Brief Illustrated Chronicle of Retroactive Copyright Term Extension' (2015) 62 Journal of the Copyright Society of the USA 479.

81 Landes and Posner, 'Indefinitely Renewable Copyright' (n 24) 497-500. 


\section{A Library eLending and OverDrive}

Today, public libraries commonly offer patrons opportunities to borrow ebooks. ${ }^{82}$ This is not as simple as it is for physical books. Acquiring and lending ebooks involves the making of copies and transmissions, and as a result, libraries require a licence from the copyright holder to do so. ${ }^{83}$ Direct licence negotiations between every library and every publisher would involve impossibly high transaction costs, so a market has emerged in which ebook 'aggregators' negotiate licences with individual publishers in various territories, and then pass them downstream. ${ }^{84}$ Public libraries then contract with one or more of these aggregators for the supply of ebooks to lend to their patrons. Library elending has become big business. In 2008 the leading global provider, Rakuten OverDrive Inc ('OverDrive') reported 10 million checkouts worldwide (including not just ebooks but also e-audio, music and video). ${ }^{85}$ By 2018, the company had grown to service some 43,000 libraries across 70 countries - and processed 185 million loans of ebooks alone. ${ }^{86}$ To put those numbers in perspective, PubTrack Digital reported just 162 million global ebook sales in $2017 .{ }^{87}$

Subscribing libraries license titles from OverDrive for elending via its online 'Marketplace' in each country. Since copyright is territorial, and OverDrive does not necessarily have the right to license all titles in all countries, librarians in Canada have access to a different selection of ebooks to choose from in the OverDrive Marketplace than librarians in New Zealand, who have access to a different selection than librarians in the US and so on.

OverDrive provides access to a small range of free material, but its central 'Marketplace' in each country only provides access to titles offered by commercial publishers. That makes it an ideal source for assessing the rates at which publishers (as distinct from individuals or cultural institutions) invest in making older titles available in the form of ebooks. And, because OverDrive charges publishers a

82 In 2015, 99\% of Australian public libraries offered ebooks: Australian Public Library Alliance, 'Comparison of Ebooks and Elending in Australian Public Libraries 2015' (Report, June 2015) 2.

83 See generally Rebecca Giblin and Kimberlee Weatherall, 'At the Intersection of Public Service and the Market: Libraries and the Future of Lending' (2015) 26(1) Australian Intellectual Property Journal 4.

84 Ibid 11.

85 Rakuten OverDrive, 'OverDrive Announces 2008 Library Download Statistics and Milestones' (Press Release, 7 January 2009) <company.overdrive.com/2009/01/06/overdrive-announces2008-library-download-statistics-and-milestones/>.

86 Rakuten OverDrive, 'Public Libraries Achieve Record-Breaking Ebook and Audiobook Usage in 2018' (Press Release, 9 January 2019) <company.OverDrive.com/2019/01/08/publiclibraries-achieve-record-breaking-ebook-and-audiobook-usage-in-2018/> .

87 Jim Milliot, 'E-Book Sales Fell 10\% in 2017', Publishers Weekly (online, 25 April 2018) <publishersweekly.com/pw/by-topic/digital/content-and-e-books/article/76706-e-book-salesfell-10-in-2017.html>. 
percentage of sales, with no hosting or title fees,${ }^{88}$ it imposes minimal additional barriers to inclusion of additional titles.

OverDrive also provides ideal conditions for testing the relationship between availability and copyright status. In related work studying the relative availability of more than 94,000 titles across five countries, we found that Australia and NZ had exceptionally high degrees of overlap in the ebooks available to their libraries, as did the US and Canada. ${ }^{89}$ That is, in each of those two country pairings, identical titles were available and unavailable at close to identical rates. However, the countries in each pair have different copyright terms. NZ has (narrowly) managed to hold onto Berne's life $+50,{ }^{90}$ but its close neighbour and trading partner Australia grants 20 years more. ${ }^{91}$ At time of writing, Canada also still grants the Berne minimum. In the US however, older works were subject to a system of renewable terms that mean some remain under copyright while others have entered the public domain..$^{92}$ This provides the conditions for a natural experiment. If the underuse hypothesis is correct, titles ought to be available via OverDrive at higher rates where they are still under copyright, and lower rates where they are in the public domain. The closely related availabilities we have demonstrated for those pairs in our related work means that we can be more confident that the differences we identify in this sample are attributable to copyright status. Further, since public libraries source books for elending almost exclusively from aggregators, our use of aggregator data controls for the possibility that publishers in countries with longer terms might be declining to invest in making ebooks available to libraries because of the possibility of competition from infringing copies.

\section{B Constructing the Sample}

In constructing the sample, we were interested in capturing titles that were:

1. 'culturally valuable'; and

88 OverDrive, Summary of Terms for OverDrive Ebook Suppliers (May 2015) <static.odcdn.com/ODSummaryOfTermseBookv201505.pdf>, archived at <perma.cc/Y5VP-JKX2>.

89 Rebecca Giblin et al, 'What Can 100,000 Books Tell Us about the International Public Library E-Lending Landscape?' (2019) 24 Information Research (forthcoming, currently available at https://dx.doi.org/).

90 New Zealand would have been required to enact a copyright term extension under the original Trans-Pacific Partnership Agreement between the Government of Australia and the Governments of: Brunei Darussalam, Canada, Chile, Japan, Malaysia, Mexico, New Zealand, Peru, Singapore, the United States of America and Vietnam, signed 4 February 2016, [2016] ATNIF 2 (not yet in force) art 18.63 ('Trans-Pacific Partnership'). However, this version of the treaty has now been abandoned and its successor omits this requirement: Comprehensive and Progressive Agreement for Trans-Pacific Partnership between the Government of Australia and the Governments of: Brunei Darussalam, Canada, Chile, Japan, Malaysia, Mexico, New Zealand, Peru, Singapore and Vietnam, signed 8 March 2018, [2018] ATS 23 (30 December 2018) ('Comprehensive and Progressive Agreement for Trans-Pacific Partnership').

91 USFTA Implementation Act (n 7) sch 9 item 120, amending Copyright Act (n 7) s 33(2).

92 See below n 97 and accompanying text. 
2. in the 'copyright/public domain window' - that time period where they are still under copyright in some jurisdictions but have elsewhere entered the public domain.

\section{1 'Culturally Valuable’}

It was important to populate our sample with 'culturally valuable' titles because books are published in large numbers and depreciate quickly. Commercial life is typically exhausted 1.4 to 5 years from publication; ${ }^{93}$ some $90 \%$ of titles become unavailable in physical form within just two years. ${ }^{94} \mathrm{Had}$ we used a purely random sample of titles in the relevant age bracket, we would have expected almost all of them to have no remaining cultural or economic value - and therefore, even if we had found them to be missing from library catalogues, that finding may not have been of particular interest. Focusing instead on titles with enduring cultural value enables us to draw more meaningful conclusions from our results.

To identify such titles we used the current versions of the Oxford Companions to English, Australian, NZ, American and Canadian literature. ${ }^{95}$ These texts contain biographical information for thousands of authors deemed significant by specialist contributors. We deemed authors' inclusion in these reference works prime facie evidence of the enduring cultural value of their books.

\section{In the 'Copyright/Public Domain Window'}

We were interested in authors whose works were in the public domain in some countries but remained under copyright in others. That would enable us to study the relative availability of the same titles in markets where publishers have exclusive rights and where they do not, taking advantage of the natural experiment described above. We selected all Oxford Companion authors who had died between 1962 and 1967. That resulted in a novel list of 250 authors, among which some of the most notable included Aldous Huxley, Sylvia Plath and Ian Fleming. ${ }^{96}$ Aside from unusual cases (involving, for example, posthumous or pseudonymous publication), all books by these authors have entered the public domain in NZ and Canada, and remain under copyright in Australia. In the US, as developed further below, they can have either status, depending on their original publication date and whether their owners renewed their short initial term.

93 Productivity Commission, 'Intellectual Property Arrangements' (Inquiry Report No 78, 23 September 2016) 130, citing Australian Bureau of Statistics, Australian System of National Accounts: Concepts, Sources and Methods (Catalogue No 5216.0, 2015) 376.

94 Productivity Commission (n 93) 130.

95 Dinah Birch (ed), The Oxford Companion to English Literature (Oxford University Press, $7^{\text {th }}$ ed, 2009); William H Wilde, Joy Hooton and Barry Andrews, The Oxford Companion to Australian Literature (Oxford University Press, $2^{\text {nd }}$ ed, 1994); Roger Robinson and Nelson Wattle (eds), The Oxford Companion to New Zealand Literature (Oxford University Press, 1998); James D Hart and Phillip W Leininger, The Oxford Companion to American Literature (Oxford University Press, $6^{\text {th }}$ ed, 1995); Eugene Benson and William Toye (eds), The Oxford Companion to Canadian Literature (Oxford University Press, $2^{\text {nd }} \mathrm{ed}, 1997$ ).

96 For the full author list, see below Appendix I. 
It may be that the sampled authors have different levels of popularity in different jurisdictions - that there is greater demand for some Canadian authors in Canada, for example, and some greater demand for some Australian authors in Australia. Our preliminary testing found no consistent effect related to nationality and so we have not controlled for this. However, it is possible that differing regional demand could explain some part of the variation in our results.

\section{Collecting and Cleaning the Data}

We collected availability data from OverDrive in April 2018, using a script to query the 250 author names in its distinct 'Marketplaces' for Australia, NZ, the US and Canada. While OverDrive has several distinct ebook sources, its 'Marketplaces' contain the offerings from commercial publishers we wanted to study. We then cleaned the data, excluding works to which sampled authors made non-substantial contributions (eg only forewords), those by homonymous authors (the Ian Fleming of James Bond fame was in; the Ian Fleming who wrote management training manuals was out), translations, posthumous publications (to which different copyright rules apply) and so on. For 23 authors, only these excluded categories of works were available, effectively removing those authors from the sample. ${ }^{97}$ This left us with 3,224 records authored by our 227 sampled authors and made available by publishers to libraries across Australia, NZ, the US and Canada.

We then took an additional step to verify the copyright status of US titles, which, as noted above, depends on their original publication date and renewal status. When we collected our data in 2018, works were still under US copyright if they had been published between 1923-67 and their initial term had been renewed by the copyright owner. ${ }^{98}$ Titles published before 1923, or between 1923-67 but not renewed, were in the public domain. Our sample contains 521 distinct titles available in the US. Of these, 373 were published between 1923-63. We established the copyright status of each title by searching the Stanford Copyright Renewals Database, which contains a complete list of Class A (book) renewals received by the US Copyright Office during the relevant period. ${ }^{99}$ Our search found copyright to have been renewed for 272 of the 373 books (72.9\%), with the remaining 101 entering the public domain. By way of comparison, the renewal rate for all works

97 These authors are identified in Appendix I.

98 Works published before 1923 entered the public domain before 27 October 1998 and were therefore not eligible for the 1998 term extension: Copyright Term Extension Act (n 5) § 102(d)(1)(B), amending 17 USC $\S 134(b)$ (2012). See also Brauneis (n 80) 20-1; 'Copyright Term and the Public Domain in the United States', Cornell University Library: Copyright Information Centre (Web Page, 7 February 2019) <copyright.cornell.edu/publicdomain>. Works published between 1923-63, and in which copyright was renewed, were still within their renewal term on 27 October 1998 and were therefore eligible for the term extension. However, works published between 1923-63, and in which copyright was not renewed, were not eligible. See also Brauneis (n 80) 20; Menesha A Mannapperuma et al, Is It in the Public Domain? A Handbook for Evaluating the Copyright Status of a Work Created in the United States between January 1, 1923 and December 31, 1977 (Berkeley Law, 2014).

99 'Copyright Renewals', Stanford Libraries (Web $\quad$ Page) <exhibits.stanford.edu/copyrightrenewals?forward=home>. 
ranged from 3\% in 1914 to a peak of approximately $22 \%$ in $1991 .{ }^{100}$ For books, generally, renewal rates average around 8\%. ${ }^{101}$ Landes and Posner have used renewal data as a proxy for determining the rates at which works lose value, arguing that 'the fact that a small fraction of works are renewed implies that most copyrights have very little economic value after twenty-eight years' ${ }^{102}$ The relatively high renewal rate for the titles in our sample suggests that they were more likely to retain commercial value than the average book of the same age, making them particularly suitable for testing the underuse hypothesis. ${ }^{103}$

\section{Title Matching}

To assess comparative availability across jurisdictions, we needed to link records at a title level. To do so, we wrote a matching algorithm that treated two records as referencing the same work if they shared an identical title and at least one identical author. Famous books are sometimes published in multiple editions with, for example, forewords by different contributors. Those contributors are often also listed as authors. By requiring the algorithm to match only one identical author (together with the identical title) we were able to match titles that had the same substantive content.

Matching records at a title level enables us to not only identify the number of distinct works made available, but also to compare availability of the same works across jurisdictions. This is a significant development over the prior literature, which compared groups of books. It allows us to compare like and like: for example, how does the availability of Aldous Huxley's Brave New World compare under copyright and in the public domain? This reduces the difficulties of accounting for different popularity across different samples of works, which complicated Heald's studies comparing newer to older books. ${ }^{104}$ As developed below, for some analyses we additionally used manual matching processes to link titles in different ways (for example, where we were calculating the books available in Jurisdiction $X$ but not Jurisdiction $Y$ ).

\section{E Understanding the Licence Types}

There are four main licence types by which books were made available to libraries in our OverDrive data: one supplying perpetual access, and the three others providing metered access. We introduce them here to facilitate understanding of the analyses that follow.

1. 'One copy, one user' or 'OC/OU' licences entitle the purchasing library to lend the title to one borrower at a time for as long as they have access to the elending aggregator's platform.

\footnotetext{
${ }^{100}$ Landes and Posner, 'Indefinitely Renewable Copyright' (n 24) 499-500.

101 Ibid 506.

102 Ibid 500.

103 See Heald, 'Property Rights and the Efficient Exploitation of Copyrighted Works' (n 40) 1036; ibid 518.

104 Heald, 'Property Rights and the Efficient Exploitation of Copyrighted Works' (n 40) 1048.
} 
2. Loan limited licences entitle the library to lend the title to one borrower at a time a set number of times (eg '26 loans'), for as long as the library has access to the platform;

3. Time limited licences entitle the library to lend the title to one borrower at a time for a set period (eg ' 12 months');

4. Time and loan limited licences entitle the library to lend the title to one borrower at a time for a set period or a set number of loans, whichever comes first (eg '36 loans or two years').

\section{F Testing the Hypothesis}

The underuse hypothesis posits that publishers will invest more in making books available where they are under copyright (and thus come with exclusive rights to prevent competition) than where they are in the public domain. We formulated several research questions to test this using various proxies for publisher willingness to invest.

1. How many distinct titles were available to libraries in each of Australia, NZ, the US and Canada? If the underuse hypothesis is correct, we should see fewer titles available where they are in the public domain than where they are still covered by copyright.

2. How many editions of each title are offered in each country? Multiple editions of public domain titles is an indicator of commercial publisher willingness to compete directly on the same titles.

3. Were any books available where they were under copyright, but not where they were in the public domain? And vice versa - were there books available in the public domain, but not where they were under copyright? Through this title level comparison we sought to identify the direction in which underinvestment (if any) was flowing.

We then asked a further two questions aimed at contextualising the publisher behaviour:

4. How did commercial publisher investments in public domain works compare to non-commercial investments?

5. How did the prices for books made available via OverDrive vary by country and copyright status?

\section{RESULTS}

\section{A Willingness of Commercial Publishers to Invest in Making Older Books Available}

As introduced above, our primary interest in this paper is to test the underuse hypothesis in the library elending context. Our first three research questions assess the willingness of commercial publishers to invest in making older books available. Notably, as introduced above, none of the books in our sample are natively digital. Although it is cheaper to digitise texts today than ever before, publishers must still make non-trivial investments in scanning, formatting and proof reading in order to derive a saleable ebook from the original physical form. Here we report an overview of our results, followed by full details below. 
First, we measure the number of distinct titles available in each market. We find that most authors had no titles available via OverDrive, in any jurisdiction, regardless of copyright status. This shows the existence of exclusive rights is not sufficient in and of itself to incentivise investment in works. We also find that there were more distinct titles available in Canada and NZ (public domain jurisdictions) than Australia (copyright), and that all three outperform the US (mixed copyright and public domain), suggesting that extended rights may actually lead to less rather than more investment.

Second, we measure the number of editions offered in each country. We find a greater number of editions of each title in public domain countries, demonstrating that commercial publishers are willing to invest in making works available even in the face of direct competition.

Third, we identify all cases in which titles were available in copyright jurisdictions but not public domain jurisdictions (and vice versa). Considerably more titles are 'missing' where they are under copyright than where they are in the public domain, again suggesting that extended rights may actually lead to less investment than would otherwise have occurred. These results are developed below.

\section{How Many Distinct Titles Were Available in Each Market?}

For 135 of the 227 sampled authors (59\%), we found that commercial publishers made no ebooks available to libraries to license in any of Australia, NZ, the US or Canada. Authors with zero books included five Pulitzer Prize winners (Van Wyck Brooks, Russel Crouse, Esther Forbes, Frank Luther Mott and Elmer Rice); renowned philosopher Alexander Meiklejohn; and prominent Australians Dame Mary Gilmore and David Unaipon, whose portraits feature on the Australian \$10 and $\$ 50$ bank notes. ${ }^{105}$ This is particularly striking since, as noted above, OverDrive only charges publishers a percentage of actual sales (with no hosting or service charges), thus imposing minimal barriers to additional works being made available.

Commercial publishers made at least one ebook available in at least one jurisdiction for the remaining 92 authors. Of these, $30(33 \%)$ had only one title available, and $70(76 \%)$ had eight or fewer (see chart showing titles by author at Figure 1). A number of prolific and well-known writers had just a fraction of their work represented. For example, e e cummings authored over 30 books, ${ }^{106}$ but just seven titles were available to libraries for elending. Four-time Pulitzer Prize winner Robert Lee Frost had six distinct titles available to libraries in ebook form. ${ }^{107}$ Only

\footnotetext{
105 See full list of authors with no titles available for elending below at Appendix I.

106 Centre for the Book at the New Hampshire State Library, 'Bibliography: e e cummings', New Hampshire State Library (January 2007) <nh.gov/nhsl/bookcenter/programs/spotlights/documents/eecummingsbio.pdf>.

107 In fact, there was substantial overlap between these six titles: A Boy's Will; A Boy's Will and North of Boston; A Boy's Will, Mountain Interval; Mountain Interval; North of Boston; and Selected Poems.
} 
five of Nobel Laureate T S Eliot's $80+$ titles $^{108}$ were available, and there was just one from fellow Laureate Hermann Hesse.

These results are even more striking for the fact that they come from a sample of older books that is disproportionately likely to have ongoing value. If we were to scale up to the entire publishing industry, we would expect overall availability for older books to be considerably worse than the picture painted here. These results show that the existence of exclusive rights is not sufficient, in and of itself, to incentivise commercial investment in works, even when they have ongoing cultural value.

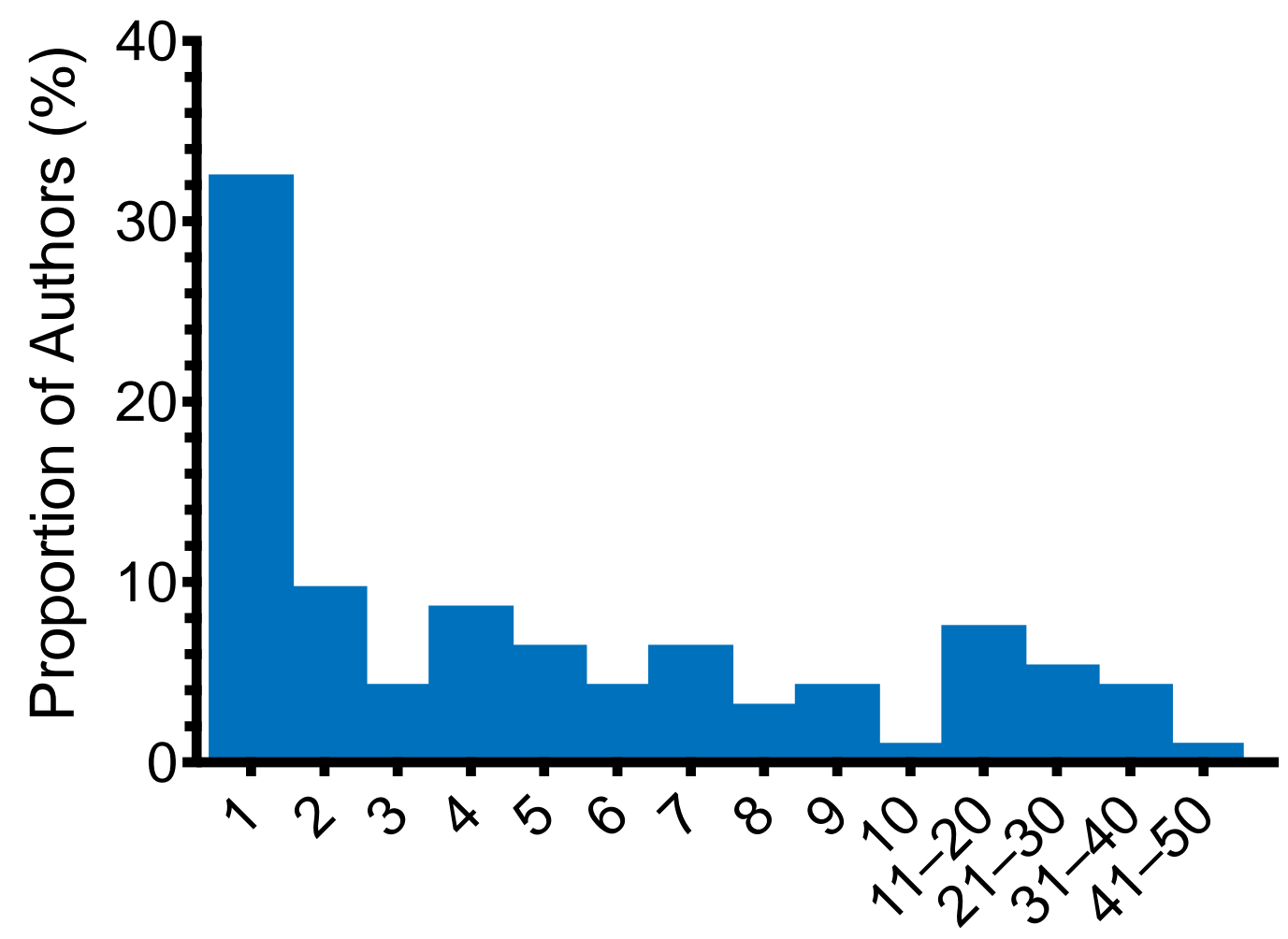

Number of Titles

FIGURE 1: Distribution of the number of titles among the 92 authors with ebooks available.

${ }^{108} T \quad S \quad$ Eliot Bibliography (Web Page, 31 January 2019) Wikipedia <en.wikipedia.org/wiki/T._S._Eliot_bibliography>. 
After using our title matching algorithm to link records across jurisdictions, we next compared the number of distinct ebooks available in each. The US had the fewest distinct titles available (521 total, including 276 in copyright and 245 in its public domain), followed by Australia (551), NZ (582), and Canada (599). These results are charted at Figure 2.

These ratios were substantially different to those we detected in our control dataset of 94,328 titles (the 'large-scale sample') developed in our related work. ${ }^{109}$ There, we found very high degrees of overlap in the books that were available in two pairs of countries: Australia with NZ, and the US with Canada. On that large-scale sample, $99.7 \%$ of the books available to NZ public libraries were also available to Australian ones, and $99 \%$ of the books available to Australian public libraries were also available to NZ ones. $97 \%$ of the books available to Canadian libraries were also available to US libraries, and $97.6 \%$ of the books available to US libraries were also available to Canadian ones. Other country pairings had markedly lower similarities: for example, only $78.8 \%$ of books available to US libraries were also available to Australian libraries. These results provide a baseline for the degree of similarity we would expect for each pair of jurisdictions. To the extent that greater differences are found, they are more likely to be attributable to copyright status.

In the large-scale sample Canada had $0.6 \%$ more titles available than the US, but in the public domain it had $15 \%$ more. NZ had $0.7 \%$ more titles than Australia in the control dataset, but $5.6 \%$ more in the public domain sample. We also observed that NZ had $10.5 \%$ fewer books than the US in the control, but $11.7 \%$ more in the public domain sample. However, there was less similarity between NZ and the US in the control sample (65664 of NZ's 74799 titles were also available in the US, 87.8\%) and so, while this result is highly striking, we can be less confident that the difference is attributable to copyright status.

These results are particularly interesting given the US's status as the world's most valuable book market, ${ }^{110}$ with publisher revenues estimated at over US $\$ 26$ billion in 2017. ${ }^{111} \mathrm{NZ}$ had access to more titles in the public domain sample despite its book market being worth a fractional $1 \%$ of that amount ${ }^{112}$ — and Canada had more still. The strong showing by the two public domain countries suggests a marked willingness by publishers to invest in making derivative ebooks available in the absence of exclusive rights.

109 Giblin et al, 'What Can 100,000 Books Tell Us about the International Public Library E-Lending Landscape?' (n 89).

${ }^{110}$ Deloitte, 'Print Is Alive and Well - At Least for Books' (2015) $<$ deloitte.com/content/dam/Deloitte/global/Documents/Technology-MediaTelecommunications/gx-tmt-pred15-print-alive-and-well.pdf>.

111 Porter Anderson, 'StatShot Annual Publisher Survey Put 2017 Estimated US Revenue at \$26.2 Billion', Publishing Perspectives (online, 23 July 2018) <publishingperspectives.com/2018/07/us-statshot-publisher-survey-2017-estimates-revenue>.

112 In 2015, the market value of the New Zealand publishing industry was estimated at NZ\$397 million: 'Economic Contribution of the New Zealand Book Publishing Industry 2015' (PricewaterhouseCoopers, November 2016) 8. 
Notably, even Australia had more titles available to libraries than the US. All sampled titles were under copyright in Australia, compared to a mix of copyright and public domain in the US. We hypothesise that the relative lack of investment in the US market may be partially explained by higher tracing costs and large potential liability for getting it wrong. It is more difficult to determine whether pre1963 works are in the public domain under the US framework due to its previous renewal system, ${ }^{113}$ and those who make an error not only risk costly infringement proceedings but also the threat of statutory damages of up to US $\$ 150,000$ per infringement. ${ }^{114}$ Those factors may be discouraging publishers from investing in public domain works in the US as much as elsewhere.

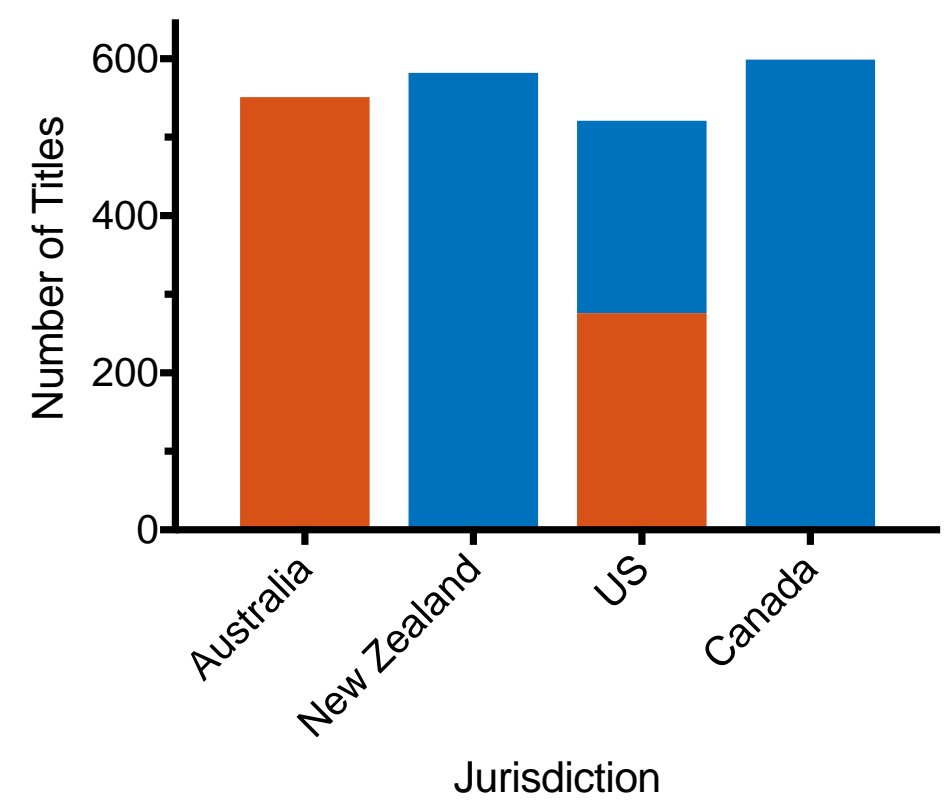

Copyright

- Public Domain

FIGURE 2: Number of titles available and copyright status for each jurisdiction.

\section{How Many Licences Were Offered for Each Title in Each Country?}

The analysis above tested the underuse hypothesis by comparing the number of distinct titles available in each jurisdiction. However, it is possible for the same title to be made available to libraries via multiple offerings, perhaps at different price points or by different providers. We have shown in related work that copyright titles usually have only a small number of offerings, since ebook rights in a given jurisdiction are typically controlled by a single publisher. ${ }^{15}$ But what about public domain works? Conventional economic theory suggests publishers would keep investing in editions for as long as they can make a profit, while the underuse theory suggests publishers will not invest unless they have exclusive rights. We measured the number of licences offered for the sampled titles to see which theory is better

113 See generally Mannapperuma et al (n 98).

11417 USC $\S 504(c)(1)-(2)(2012)$.

115 Rebecca Giblin et al, 'Available - But Not Accessible? Investigating Publisher E-Lending Licensing Practices' (2019) 24 Information Research (forthcoming) ('Available — But Not Accessible?'). 
supported by the data. The hypothesis to test was whether titles in the public domain had more licence offerings than the same titles when they are under copyright.

The number of licences per title is not a perfect measure. OverDrive representatives told us in an interview that they aim to discourage multiple editions of public domain works unless subsequent editions add substantial value - for example, through additional editorial content. ${ }^{116}$ This policy would not place any downward pressure on the first offering of a work, but could potentially do so for subsequent licences. Having said that, it is enforced haphazardly at best: on our large-scale sample, we found over 160 offerings for Sir Arthur Conan Doyle's Adventures of Sherlock Holmes in a single jurisdiction. ${ }^{117}$ Thus, although aware that the number of licences per title may underestimate publishers' willingness to invest in public domain works, we still see it as a useful proxy.

We found that titles were available with more licences in NZ than in Australia. We also found that Canada had more licences than the US. As developed below, these results are highly statistically significant, strongly supporting the hypothesis that titles in the public domain had more licence offerings than the same titles when they are under copyright.

To obtain these results, we calculated how many licences were available for each title in each jurisdiction. This includes titles with no licences at all (ie titles that were unavailable were counted as having 0 licences). For each of the 661 distinct titles in our sample, we compared our two paired jurisdictions (NZ vs Australia and Canada vs US). NZ had 100 titles for which more licences were available than in Australia, 561 titles for which an equal number of licences were available, and 0 titles for which fewer licences were available. We calculated statistical significance by using the non-parametric Wilcoxon signed-rank test, which enables calculation of the significance of such wins (when NZ has more), draws (when NZ and Australia have an equal number) and losses (when Australia had more). The result was highly statistically significant $\left(\mathrm{p}<10^{-9}\right)$, ie less than one chance in a billion that this result is due to chance. Canada had 212 titles for which more licences were available than in the US, and 367 titles for which an equal number were available, and 82 titles for which it had fewer. This result was also highly significant $\left(\mathrm{p}<10^{-11}\right)$; ie less than one chance in 100 billion of the result being due to chance. Notably, of the 82 titles that had more licences in the US than in Canada, 84\% (69 titles) were in the public domain in the US, and just 13 were under copyright.

Since the above analysis involved matching titles, it wasn't possible to compare the number of editions in the US public domain compared to US copyright (since, definitionally, a given title can only be in one or the other). Accordingly, we did a further analysis that examined the average number of licences per work for the US copyright and public domain groups. We found that 1.03 licences were available on average for each US copyright work. By contrast, works that had entered the US public domain averaged 1.91 licences. That is particularly striking given that the

116 Rebecca Giblin, Interview with Alexis Petric-Black, Manager, and Marla Levine, Content Sales Associate, Rakuten OverDrive (27 June 2018).

117 Giblin et al, 'What Can 100,000 Books Tell Us about the International Public Library E-Lending Landscape?' (n 89). 
US public domain works include those that were not renewed, indicating a perceived relative lack of value for those works compared to those in the copyright subsample. These results show that competition is demonstrably occurring over public domain titles, and that, as predicted by economic theory, the absence of exclusive rights is not deterring publishers from investing.

Our results observing a greater number of licence offerings for books in the public domain than in copyright is comparable to that of Heald in the context of physical books, where he observed $63 \%$ more public domain books that copyright ones. ${ }^{118}$ It's also consistent with Reimers' findings, for a set of historical bestselling fiction titles, that the shift from copyright to the public domain leads to more rather than fewer editions. ${ }^{119}$

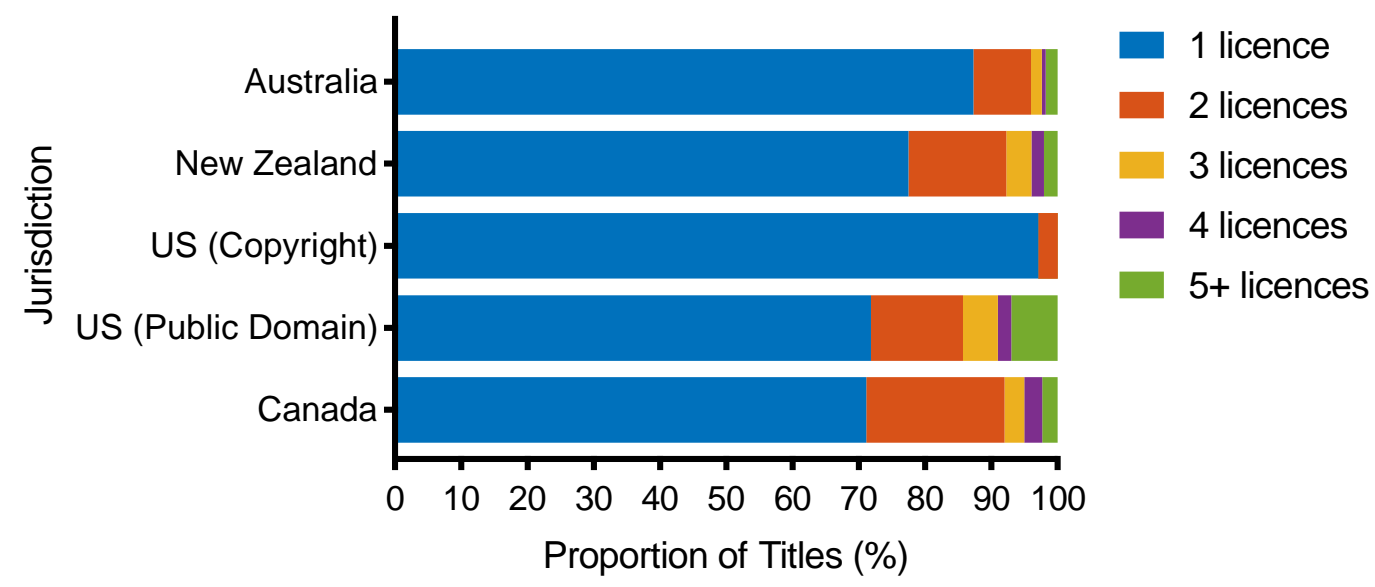

FIGURE 3: Distribution of number of licences per title for each jurisdiction.

\section{Titles Available in Copyright Jurisdictions but not Public Domain Jurisdictions (and Vice Versa)}

Because we were able to identify each distinct title appearing in our sample, and to 'match' them across jurisdictions, we were able to detect where books were and were not available. To better understand the direction in which underinvestment was occurring, we investigated which of the sampled ebooks were available in a copyright jurisdiction but unavailable in the corresponding public domain jurisdiction (and vice versa). If the underuse theory is correct, we would expect to find titles more available in copyright jurisdictions than where they are in the public domain.

At the time of data collection, all titles were under copyright in Australia, and in the public domain in NZ and Canada. US titles were in the public domain if they were published before 1923, or if published between 1923-63 but not renewed. All others remain restricted by copyright.

${ }^{118}$ Heald, 'Property Rights and the Efficient Exploitation of Copyrighted Works' (n 40) 1043. Heald reported an average of 5.2 editions of public domain books and 3.2 editions of copyrighted books.

119 Imke Reimers, 'Copyright and Generic Entry in Book Publishing' (2019) American Economic Journal: Microeconomics (forthcoming). 
In determining whether a title was available in one country but not another, we manually accounted for availability in different forms. For example, William Faulkner's two book collection Sanctuary and Requiem for a Nun was available in NZ but not in Australia. However, Sanctuary and Requiem were individually available in Australia, so we counted it as available there for this analysis.

We found no ebooks available in Australia (where they would be under copyright) but not in NZ (where they would be in the public domain). However, we identified 12 ebooks that were available in NZ (public domain) but not in Australia (copyright). ${ }^{120}$ These included titles by notable authors such as C S Lewis, William Faulkner and Flannery O'Connor.

In North America, we identified 101 titles available in Canada but not in the US. ${ }^{121}$ In the other direction, 11 titles were available under copyright in the US but unavailable in Canada, ${ }^{122}$ and 27 titles were available in the US public domain but not available in Canada, where they would also be in the public domain. ${ }^{123}$ That so many more titles were available in Canada than the US is particularly striking. Canada's population is a tenth the size of its southern neighbour, making investments in older works relatively less attractive. Nonetheless, Canada is where commercial publishers have invested in making more works available.

These results suggest that, at least for older, culturally valuable works with low fixed and marginal costs of production and distribution, underinvestment may flow from the existence of copyright rights, rather than from their absence.

120 These titles were William Faulkner's Mosquitoes, Pylon and Sartoris; Ian Fleming's Automobilia; Wilfrid Wilson Gibson's Friends; CS Lewis' The Pilgrim's Regress and Till We Have Faces; AJ Liebling's Chicago; Flannery O'Connor's The Violent Bear It Away; Frank O'Hara's Jackson Pollock; and Eleanor Roosevelt's On My Own and This Is My Story.

121 These titles included three by Margery Allingham, one by Brendan Behan, five by Isak Dinesen, two by TS Eliot, one by Eleanor Farjeon, one by William Faulkner, 17 by Ian Fleming, 16 by CS Forester, two by Ben Hecht, five by Aldous Huxley, two by Patrick Kavanagh, three by Eric Lambert, two by CS Lewis, one by Louis MacNeice, 13 by W Somerset Maugham, two by Flann O'Brien, one by Martha Ostenso, six by Arthur Ransome, one by Eleanor Roosevelt, one by Alice B Toklas, one by Henry Treece and 15 by Evelyn Waugh.

122 These titles were Margery Allingham's The Crime at Black Dudley, Dancers in Mourning, Flowers for the Judge, Death of a Ghost and the Case of the Late Pig and Traitor's Purse; Isak Dinesen's Last Tales; Eleanor Farjeon's The Little Bookroom; Aldous Huxley's Collected Short Stories; Siegfried Sassoon's Memoirs of a Fox-Hunting Man, Memoirs of an Infantry Officer and Sherston's Progress; and TH White's Mistress Masham's Repose.

123 These titles were Winston Churchill's Liberalism and the Social Problem; Patrick Hamilton's The Slaves of Solitude and Twenty Thousand Streets under the Sky; Aldous Huxley's Leda and Limbo; John Masefield's Good Friday, King Cole, Philip the King, Reynard the Fox, Right Royal, The Campden Wonder and Mrs Harrison, The Daffodil Fields, The Everlasting Mercy, The Faithful, The Locked Chest \& The Sweeps of Ninety-Eight, The Old Front Line, The Tragedy of Nan, The Tragedy of Pompey the Great, The Window in the Bye Street and William Shakespeare; W Somerset Maugham's The Bishop's Apron; Eleanor Roosevelt's Eleanor Roosevelt's Book of Common Sense Etiquette and This Troubled World; Vita Sackville-West's Sissinghurst; EE 'Doc' Smith's Vortex Blaster; Carl Van Vechten's Lords of the Housetops; and Arthur Waley's The Way and Its Power; A Study of the Tao Tê Ching. 
These first three questions directly tested the underuse hypothesis. Not only did we find no evidence in support, but indeed we found what appears to be a positive public domain effect: that titles are more available, and in a greater number of editions, where they are in the public domain than where they are under copyright. Longer exclusive rights for older, 'culturally valuable' titles demonstrably results in less investment than where those titles were permitted to enter the public domain. Furthermore, the mere existence of exclusive rights is shown not to be sufficient to incentivise investment in the absence of some commercial market, and where such a market exists, publishers seem far less put off by the prospect of competition than the underuse hypothesis asserts.

\section{B How Does Commercial Availability in the US Compare to Non-Commercial Availability?}

Above, we report evidence that commercial publishers invest more in works that are in the public domain than those for which they have exclusive rights, as well as willingness to compete with one another by investing in multiple editions of the same titles. However, we also observed that just over $40 \%$ of our 'culturally valuable' authors had even one book available. Here, we further contextualise the observed behaviour of commercial publishers by comparing commercial availability of public domain ebooks to non-commercial availability via Project Gutenberg. ${ }^{124}$ Project Gutenberg is a volunteer-run program that digitises public domain books and makes them available to the public online for free - over 57,000 as of November 2018, when we collected our availability data from its website. ${ }^{125}$ By comparing availability on the US OverDrive marketplace to that on the US Gutenberg site, we sought to see whether there was any support for the underuse hypothesis: after all, widespread availability from alternative (free) sources may potentially lead to downward pressure on commercial investment.

Across the commercial (OverDrive) and non-commercial (Project Gutenberg) platforms, we found a total of 338 titles by our sampled authors. Of these, 112 (33\%) were available via both. That is to say, of the 245 titles made available by commercial publishers on OverDrive, $112(46 \%)$ were also available for free via Project Gutenberg. And, reciprocally, of the 205 titles on Project Gutenberg, 112 $(55 \%)$ were also available commercially via OverDrive. Of the remaining 226 titles, 133 were available exclusively on the US OverDrive site and 93 were available exclusively via Project Gutenberg. In total, US libraries had commercial access to around $20 \%$ more titles from commercial publishers via OverDrive than did the general public via Project Gutenberg.

124 OverDrive also has a separate section of its website that provides libraries with free access to a limited selection of Project Gutenberg texts. At time of writing, it offered access to 4843 texts compared to the full project's 57,000 at the time we collected our data: 'Project Gutenberg', Rakuten OverDrive (Web Page) <overdrive.com/publishers/project-gutenberg>; Project Gutenberg (Web Page, 27 May 2019) <gutenberg.org>. We did not include Project Gutenberg offerings via OverDrive in the data collected above because our focus was on commercial offerings.

125 Project Gutenberg (n 124). 
We also calculated the number of titles made available per author via each platform. While individual authors' availabilities varied substantially, overall OverDrive had more titles available per author (mean $=4.1$, median $=2$ ) than Project Gutenberg $($ mean $=3.3$, median $=1)$.

Consistent with our previous findings, these results demonstrate considerable willingness by publishers to invest in making ebooks commercially available absent exclusive rights, even in the face of competition from non-commercial sources. Interestingly, it also shows that commercial publishers are investing in making more works available to libraries than the leading non-commercial source is to the public. Having said that, it is striking that close to half the books available via OverDrive are not available via Gutenberg (and vice versa). This may suggest volunteers and commercial publishers apply different criteria in deciding which older texts to digitise.

\section{How Did Price Differ by Copyright Status?}

In our final analyses, we examined the prices charged for books on OverDrive and how they differ according to copyright status. Our hypothesis was that books are more expensive when under copyright than when they are in the public domain. As developed below, we indeed found that titles are considerably more expensive, on average, when they're under copyright than where they are in the public domain, and that those differences exceed the royalties that would be paid to authors or their heirs.

\section{Calculating Price Differences}

Comparing OverDrive prices across jurisdictions is challenging. For one thing, there may well be a different number of offerings for a title in a given country. For example, there are eight versions of Aldous Huxley's Brave New World available to libraries in Canada, but only one available to libraries in the US. Different results will be reached for price analyses depending on whether they include all offerings, some, or just one. Second, books may be licenced on different terms in different jurisdictions. If a title costs US $\$ 13$ for ' 26 checkouts' in one jurisdiction, and US\$21 for an unlimited 'OC/OU' licence elsewhere, which is cheaper? Assumptions inescapably have to be made in order to compare them.

There is no perfect solution to these challenges, and so we respond to them by conducting three distinct analyses. First, we calculate the mean price for each licence type in each jurisdiction. The aim of this analysis is to see whether, at an aggregate level, we can distinguish differences between pricing of public domain and copyright books. This aggregate analysis provides a useful preliminary picture. However, since titles may be licensed on different terms in different jurisdictions, prices may be influenced by those differences rather than copyright status. Thus, in our second analysis, we compare all books regardless of licence terms. We do this by studying the price per circulation of titles as a function of the number of circulations. That is, we calculate an overall price per circulation for all titles in each jurisdiction (ie the cost to a library of loaning the e-book to a patron once, 
twice, three times etc). This enables us to compare prices across different licence types, providing a more complete picture of book price. However, as with the first analysis, this provides only an aggregate picture. It does not control for the fact that there are differences in the available titles in the various jurisdictions. For example, Margery Allingham's Dancers in Mourning is available on an OC/OU licence for US\$13.99 in the US, and is not available at all in Canada; that impacts aggregate results in both Canada and the US. Nor does it control for potential differences in price that arise from, for example, the available books in one jurisdiction having different page counts to those in another. ${ }^{126}$ Our final price analysis controls for both, by comparing, at a title level, prices of only those books that appear in both jurisdictions of each country pair.

For each analysis we calculated two sets of prices for the US: one for its copyright titles and one for titles in its public domain. We also converted all prices to US dollars, approximating OverDrive's own currency conversion process.

\section{Mean Price by Licence Type}

In this first price analysis we compare the mean prices, in each jurisdiction, of the four main licence types: OC/OU, loan limited, time limited, and time + loan limited. These licences were explained above. ${ }^{127}$

Since this analysis involved unpaired samples with potentially unequal variances, we used the Welch t-test to assess statistical significance of results. We indicate the statistical significance ( $\mathrm{p}$-value) in brackets below.

We observed that public domain titles were almost always cheaper than copyright ones, as follows:

US public domain versus US copyright

- OC/OU titles averaged US\$9.06 compared to US\$28.63 $\left(\mathrm{p}<10^{-24}\right)$;

- Loan limited titles averaged US\$0.28 per loan compared to US\$0.52 per loan $\left(\mathrm{p}<10^{-3}\right)$

- Time limited titles averaged US\$3.28 per year compared to US\$20.99 (statistical significance could not be assessed as there was only one title under this licence in the copyright sample);

- Time + loan limited titles averaged US\$0.15 per loan compared to US\$0.52 $\left(\mathrm{p}<10^{-9}\right)$. Note that we calculated these prices by assuming these titles would be lent the maximum number of loans permitted under the licence, usually either 36 or 52 .

Canada vs US copyright

- OC/OU titles averaged US\$14.17 compared to US\$28.63 $\left(\mathrm{p}<10^{-15}\right)$;

- Loan limited titles averaged US\$0.22 per loan compared to US\$0.52 per loan $\left(\mathrm{p}<10^{-16}\right)$;

126 Buccafusco and Heald found this affected prices in an earlier study, and thus calculated their prices on a 'per page' basis: Buccafusco and Heald (n 13) 23.

127 See above Part III(E). 
- Time limited titles averaged US\$4.43 per year compared to US\$20.99 (statistical significance could not be assessed as there was only one title under this licence in the copyright sample);

- Time + loan limited titles averaged US $\$ 0.33$ per loan compared to US $\$ 0.52$ $\left(\mathrm{p}<10^{-3}\right)$.

Interestingly, those differences were reduced or reversed when comparing Canadian prices to those of the US public domain subsample. While all licence types were cheaper in Canada than in US (copyright), OC/OU, time limited and time + loan limited licences were all cheaper in the US public domain than in Canada.

\section{NZ vs Australia}

- OC/OU titles averaged US\$11.55 compared to US\$11.70 ( $p \approx 0.45$, ie not significant);

- Loan limited titles averaged US\$0.21 per loan compared to US\$0.46 per loan $\left(p<10^{-11}\right)$;

- Time limited titles averaged US\$4.26 per year compared to US\$2.99. This reverse result (supporting the opposite hypothesis) reached only $p \approx 0.14$, ie not significant;

- Time + loan limited titles averaged US\$0.34 per loan compared to US\$0.38 $(p<0.03)$.

These price differences are striking. US (copyright) titles are more expensive than Canadian (public domain) titles by up to $136 \%$, while US (public domain) titles are almost universally cheaper than the Canadian offerings. These price differences are consistent with those observed in previous studies. For example, Heald reported an $81 \%$ premium on physical books under copyright compared to those in the public domain, while Reimers found a difference of up to $35 \%$ and Li et al about $100 \% .^{128}$

These large differences are unlikely to be explained by the fact that publishers of copyright ebooks pay royalties, which are typically around $10 \%$ of recommended retail price for print books and 25\% of net receipts for ebooks. ${ }^{129}$ Publisher investments in new forewords or annotations are also unlikely to account for such sizeable differences.

The difference between public domain and copyright prices was lower between NZ and Australia, but still apparent. Loan limited titles were 54\% cheaper in NZ, and time + loan limited titles $10.5 \%$ cheaper, while the differences between OC/OU and time limited licences were not statistically significant. We hypothesise that this may

128 Heald, 'Property Rights and the Efficient Exploitation of Copyrighted Works' (n 40) 1048; Reimers (n 119); Xing Li, Megan MacGarvie and Petra Moser, 'Dead Poets' Property: How Does Copyright Influence Price?' (2018) 49(1) Rand Journal of Economics 181.

129 See, eg, 'Half of Net Proceeds Is the Fair Royalty Rate for Ebooks', The Authors Guild (Web Page, 9 July 2015) <authorsguild.org/industry-advocacy/half-of-net-proceeds-is-the-fairroyalty-rate-for-e-books>; Alex Adsett, 'Just a Standard Contract', Writers Victoria (Web Page, 15 March 2014) <writersvictoria.org.au/resources/publishing-tips-and-tools/just-standardcontract>; Eloise Keating, 'Status Update: Ebooks', Bookseller + Publisher Magazine (Melbourne), July 2011, 14. 
be due to the Australian market being bigger than that of NZ, and thus it being more worthwhile for publishers to compete for sales via price. See further below the section on 'Unexpected Publisher Behaviour'.

\section{Cost per Circulation}

For our second price analysis we calculate each licence's 'cost per circulation'. If a title is lent out once, the cost per circulation equals the full licence price, regardless of whether the title is licensed on OC/OU or metered access terms. For two loans, the cost per circulation is the full licence price divided by two, and so on. For OC/OU titles, the calculation proceeds ad infinitum. For metered access titles however it's necessary to factor in the cost of purchasing additional licences upon expiry. For example, for a 26 checkout licence, the cost of 12 checkouts is the cost of purchasing one licence divided by 12 . The cost of 27 checkouts is the cost of purchasing two licences divided by $27 .{ }^{130}$

With the per circulation price analysis we again observed that, for the most part, public domain ebooks were priced lower than those under copyright. We calculated prices on 5, 13 and 20 circulations. The price for 13 circulations is particularly notable since, in our related work examining over 7 million loans, that's the median number of times we calculated a library ebook is circulated. ${ }^{131}$

In NZ and Australia, the respective mean prices per circulation were US\$2.28 and US $\$ 2.58$ at 5 circulations $(p<0.01)$; US $\$ 0.88$ and US $\$ 0.99$ at 13 circulations $(p<0.01)$; US\$0.57 and US\$0.65 at 20 circulations $(p<0.01)$.

As between Canada and the US (copyright), the results were even more striking. The respective mean prices per circulation were US\$2.50 and US\$5.24 at 5 circulations; US\$0.96 and US\$2.02 at 13 circulations; US\$0.62 and US\$1.31 at 20 circulations (all $p<10^{-23}$ ).

As between the US (public domain) and US (copyright), for 5, 13, 20 circulations the results were US $\$ 1.67$ vs US $\$ 5.24$, US $\$ 0.64$ vs US $\$ 2.02$, and US $\$ 0.42$ vs US\$1.31 (all $p<10^{-33}$ ).

Finally, we note that as between Canada and the US (total), of which some are in copyright and others in the public domain, Canadian prices are still significantly cheaper $(p<0.001)$ with prices for 5,13 and 20 circulations being US $\$ 2.50$ vs US $\$ 3.02$, US $\$ 0.96$ vs US $\$ 1.16$, and US $\$ 0.62$ vs US $\$ 0.76$ respectively.

130 Our estimation is based on conservative assumptions. Where licences stipulated a maximum number of loans, we assumed that they would be loaned this maximum number of times before needing to be repurchased. Where licences were only limited by time, we assumed that they would be loaned every two weeks until expiry, at which point they would be repurchased. Where licences were limited by neither time nor number of loans, we assumed that they would be loaned every two weeks for three years (ie, 78 times) before being repurchased. These assumptions are consistent with those adopted in our related work: Our Methods (Web Page) <elendingproject.org/methodology.html>.

131 Giblin et al, 'Available — But Not Accessible?' (n 115). 
This analysis again consistently shows significant variations between copyright and public domain samples that exceed the amounts that would be payable in royalties or for forewords on copyright titles.

\section{Matched Title Analysis}

In this final price analysis, we compare prices at a title level. We include only titles that are available in both pairs of countries, and, where there were multiple licences available, we retained only the cheapest option, regardless of the lending model attached.

Since this analysis compares books on a title level, it controls for price differences that might be attributable to there being different titles and editions in the aggregate analyses above.

We treated very similar prices as the same in order to account for minor exchange rate differences. More precisely, if the difference between the two prices was of less than $5 \%$ of the maximum of the two prices, we considered the price to be identical.

\section{NZ vs Australia}

64 titles were cheaper in NZ than in Australia, 474 had identical prices, and 12 were more expensive in NZ. We again applied the Wilcoxon test, which found the result was significant $(p<0.001)$.

\section{Canada vs US (total)}

Canada had cheaper prices than the US for 154 titles, 274 identical prices, and 51 more expensive titles $\left(p<10^{-12}\right)$.

This result becomes even starker when we drill down further to compare Canada to the US (copyright) subgroup. There, 128 titles were cheaper in Canada, there were 109 identical prices, and 27 were more expensive in Canada $\left(p<10^{-18}\right)$. These results very strongly support the hypothesis that books are more expensive when under copyright than when they are in the public domain.

Consistently, results were much more mixed when we compared the two public domain samples (Canada and US public domain). These titles were in the public domain in both jurisdictions. They were identically priced in 165 cases, cheaper in Canada in 26 cases, and cheaper in the US in 24 cases ( $p \approx 0.37$, ie not significant).

\section{Unexpected Publisher Behaviour}

It is a core tenet of economic theory that, as competitors enter a market, prices will be driven down towards the marginal cost of delivery. Where a work is restricted by copyright there can be no (legitimate) competition, but that changes once it enters the public domain. The lower prices we found in the aggregate for public domain versus copyright titles supports this theory. Within our data however, we also observed some unexpected behaviour: publishers widely maintaining 
consistent prices for individual ebooks even where they had entered the public domain and had attracted competition.

We identified 62 examples of publishers offering titles at the same licence and price in two jurisdictions despite the fact that the title was under copyright in one and in the public domain in the other. For example, Random House makes Aldous Huxley's Brave New World available via a '36 loans or 24 months' licence for US\$15.76 in both Australia and NZ. This is despite the fact that alternative ' 52 loans or 24 months' licences for that same book were also available in NZ for as little as US\$0.99.

In some cases, publishers seem to have responded to a work entering the public domain by introducing additional, cheaper licences while simultaneously maintaining their previous offerings. For example, HarperCollins offered Sylvia Plath's The Bell Jar via a single licence in the US (US\$17.99), where it is under copyright. It offered the book on identical licence terms in Canada at four progressively lower prices (US\$7.75, US\$4.64, US\$2.32 and US\$1.54). In each of these cases, we hypothesise that publishers were relying on brand reputation, or potentially library purchasers not understanding that certain titles were in the public domain and thus available at a cheaper price from other sources. Thus, while we did detect a downward price trend where there was competition for public domain titles, not all publishers behaved as predicted, and prices tended to remain considerably above marginal cost even in the presence of competition.

\section{DISCUSSION AND CONCLUSIONS}

When the US term extension was enacted in 1998, one of the key supporting justifications was that it would improve availability for existing works. ${ }^{132}$

However, the theory that additional rights would cause rightholders to invest in the ongoing distribution of their works has not been borne out by the evidence. Above, we canvassed a small but persuasive body of empirical evidence that showed a lack of any support for the underuse hypothesis in the US context. In this paper, we contributed to the evidence-base by testing the theory outside the US market, and with the first ever cross-country comparison at the title level. Our results show that, at least where fixed and marginal costs of production are relatively low, there is no evidence that the presence of competitors for the same works deters investment. Instead, publishers are investing in making works available where they believe that there is some sufficient market for them, and are not where there is not, regardless of copyright status - just as conventional economic theory predicts. Indeed, our results show that works are more available from commercial publishers when they are in the public domain than when the same books are under copyright.

If we factor in that NZ and Canadian book markets are a fraction of the size of the US market, those results are starker still. Not only are additional rights not necessary to incentivise commercial publishers to make marketable works

132 House of Representatives Committee on the Judiciary, 'Copyright Term Extension Act' (n 25)

4. On other justifications for the extension, see above nn 25-6 and accompanying text. 
available, they actually correlate with less investment and less availability than for the same works without such rights. The upshot is that where copyright has been extended, libraries are being obliged to pay higher prices in exchange for worse access.

Our results also shed new light on the costs to society that arise from awarding copyrights that far outlast commercial interest. Although the authors we sampled were of sufficient ongoing cultural significance to be included in the most current editions of the Oxford Companions to Literature, just over $40 \%$ had even a single digital title made available to libraries, regardless of their copyright status. This shows that commercial exhaustion widely occurs before even the shortest minimum terms of life +50 years. It also shows that commercial interest in books can be exhausted long before their cultural value.

These results come at a time of growing awareness about the social and economic costs of copyright terms that outlast their owners' interest. In 2018, for example, the US-based Authors Guild came out against any further extensions of the US copyright term, stating that '[i]f anything, we would likely support a rollback to a term of life-plus-50 if it were politically feasible'. ${ }^{133}$ Its focus, no doubt, is on securing more direct and effective measures for improving author incomes. However, countries continue to be pressured to extend terms as the cost of trade access. NZ recently avoided having to do so by the slimmest of margins: it had agreed to a 20 year extension as part of the Trans-Pacific Partnership ${ }^{134}$ but that agreement lapsed after the US withdrew, ${ }^{135}$ and the replacement treaty eventually ratified in its stead contained no such mandate. ${ }^{136}$ Canada probably won't enjoy any such escape, having finally yielded to longstanding US pressure to extend its term in late $2018 .^{137}$

There can be no doubt that radical action is needed to address copyright's ongoing failures to secure a fair share of economic rewards to authors and promote widespread access to knowledge and culture. But it is increasingly clear that longer terms are not the answer, and indeed contribute to the problem. If it simply tacks another 20 years onto its term, Canada can expect its libraries to have worse access, while doing little or nothing to increase payments into author pockets. So what are the options for countries obliged to adopt unjustifiable terms extensions as a

133 Timothy B Lee, 'Why Mickey Mouse's 1998 Copyright Extension Probably Won’t Happen Again', ArsTechnica (online, 9 January 2018) <arstechnica.com/techpolicy/2018/01/hollywood-says-its-not-planning-another-copyright-extension-push>.

134 See Trans-Pacific Partnership Agreement Amendment Act 2016 (NZ) s 5(1), intended to give effect to art 18.63 of the Trans-Pacific Partnership (n 90). That provision provided that, where copyright term duration is calculated by reference to the death of a natural person, each Party must provide a copyright term of at least life plus 70 .

135 The Trans-Pacific Partnership (n 90) was abandoned when the US, which had previously been a driving force in its development, withdrew under a new administration: David Smith, 'Trump Withdraws from Trans-Pacific Partnership Amid Flurry of Orders', The Guardian (online, 24 January 2017) <theguardian.com/us-news/2017/jan/23/donald-trump-first-orders-trans-pacificpartnership-tpp>.

136 Comprehensive and Progressive Agreement for Trans-Pacific Partnership (n 90).

137 See above $\mathrm{n} 8$. 
condition of accessing trade markets? One promising line of approach is to rethink the ways in which those extended rights are divided up. In 'A New Copyright Bargain? Reclaiming Lost Culture and Getting Authors Paid', ${ }^{138}$ Giblin recently drew up a roadmap for an alternative copyright bargain. By introducing new reversion rights for authors, combined with safeguards against orphaning, she argues that it is possible to maintain incentives for creation and distribution, reclaim currently-lost culture, and secure to creators a fairer share - all while remaining consistent with treaty obligations. Faced with new evidence about the costs of current approaches, it may be time for nations which are locked in to costly and counter-productive copyright structures to similarly explore the 'wriggle room' left to them by treaties.

138 Rebecca Giblin, 'A New Copyright Bargain? Reclaiming Lost Culture and Getting Authors Paid' (2018) 41(3) Columbia Journal of Law and the Arts 369. 


\section{APPENDIX I: AUTHORS}

Ackerley, JR*

Akhmatova, Anna*

Aldington, Richard

Allen, LH (Leslie Holdsworth)*

Allen, Sir Carleton Kemp*

Allen, Ralph*

Allen, CR (Charles Richards)*

Allingham, Margery

Amato, Renato ('Michael')*

Anderson, John*

Andersen, Johannes C (Carl)*

Asch, Nathan*

Ashton, Julian Howard*

Auslander, Joseph*

Banning, Lex*

Barnes, Margaret Ayer*

Basso, (Joseph) Hamilton*

Bataille, Georges**

Baume, Eric (Frederick Ehrenfried)*

Beach, Sylvia

Bedford, Ruth*

Beebe, (Charles) William

Behan, Brendan

Bein, Albert*

Bell, Clive

Bemelmans, Ludwig*

Birkett, Winifred*
Lachance, Louis*

Lambert, Eric

Lane, Red*

Larsen, Nella

Le Franc, Marie*

Legg, Frank*

Lett, Lewis*

Letters, FJH (Francis Joseph Henry)*

Lewis, CS (Clive Staples)

Liebling, AJ (Abbott Joseph)

Lock, Arnold Charles Cooper*

Low, David*

Lowe, Eric*

Lowry, Robert W*

Loy, Mina (Gertrude Lowy)**

Lubbock, Percy

Luhan, Mabel Dodge

Macbeth, Madge*

MacDonald, Wilson*

MacNeice, Louis

Mann, Cecil*

Mannix, Daniel*

Marlowe, Mary*

Marshall, Alan John*

Marshall, James Vance

Masefield, John Edward

Maugham, W Somerset

No titles available on OverDrive.

** All titles excluded (for reasons such as posthumous or pseudonymous publication or other special cases). 
Blackmur, RP (Richard Palmer)**

Blitzstein, Marc*

Braithwaite, William Stanley Beaumont*

Breton, André**

Briggs, Ernest*

Brooke, Jocelyn

Brookes, Herbert*

Brooks, Van Wyck*

Bruno, Frank*

Burdekin, Katherine*

Burdon, RM (Randal Mathews)*

Burgess, Thorton W (Waldo)

Carson, Rachel

Casey, Gavin*

Charbonneau, Robert*

Churchill, Sir Winston

Clark, Russell*

Cocteau, Jean**

Cody, JF (Joseph Frederick)*

Connolly, Roy*

Corkery, Daniel*

Costain, Thomas B (Bertram)

Courage, James*

Craig, Gordon*

Cross, Zora*

Crouse, Russel*

Cummings, EE (Edward Estlin)

Currie, AE (Archibald Erned)*

Cutlack, FM (Frederick Morley)

Dane, Clemence*

Davis, Clyde Brion*
Maurois, André**

McCullers, Carson (Smith)

McFee, William (Morley Punshon)*

McKellar, John*

McKinney, Jack*

Meiklejohn, Alexander*

Meller, Leslie*

Miller, E (Edmund) Morris

Miller, Perry (Gilbert Eddy)**

Morin, Paul*

Morris, Myra*

Motley, Willard*

Mott, Frank Luther*

Mulgan, Alan*

Naish, John*

Niland, D’Arcy

O’Brien, Flann

O'Casey, Sean

O’Connor, Flannery

O’Connor, Frank

O’Hara, Frank

Odets, Clifford*

Ogilvie, Will (William Henry)*

Okigbo, Christopher*

Orton, Joe**

Ostenso, Martha

Palmer, Nettie*

Paquin, Ubald*

Parker, Dorothy (Rothschild)**

Pearson, Hesketh

Peattie, Donald Culross 
De Jong, David Cornel*

De Koninck, Charles*

Desrosiers, Léo-Paul*

Devanny, Jean

Dinesen, Isak

Disney, Walt (Walter Elias)*

Dobie, J (James) Frank

Du Bois, WEB (William Edward Burghardt)

Duff, Oliver*

Dunn, Max*

Eddy, Sherwood*

Edwards, Don*

Eliot, T S (Thomas Stearns)

Evans, Allen Roy*

Evatt, HV (Herbert Vere)*

Fane, Margaret (Beatrice Osborn)*

Farjeon, Eleanor

Faulkner, William (Harrison)

Fitzpatrick, Brian**

Flavin, Martin (Archer)*

Fleming, Ian

Forbes, Esther*

Forbes, Rosita**

Forester, CS (Cecil Louis)

Frank, Waldo (David)*

Frank, Pat

Frankfurter, Felix

Freeman, Joseph*

Frost, Robert Lee

Gerard, Edwin Field*

Gernsback, Hugo**
Pennell, Joseph Stanley*

Plath, Sylvia

Porteous, RS (Richard Sydney)*

Porter, Cole*

Pound, Roscoe*

Powys, John Cowper

Pratt, EJ (Edwin John Dove)*

Prewett, Frank*

Ransome, Arthur Michell

Rayment, Tarlton*

Rees, Rosemary*

Rice (originally Reizenstein), Elmer*

Roethke, Theodore**

Rohan, Criena

Roosevelt, (Anna) Eleanor

Ross, WWE (William Wrightson Eustace)*

Rota, Bertram*

Sackville-West, Victoria Mary ('Vita')

Sandburg, Carl August

Sandoz, Mari

Sanger, Margaret (Higgins)

Sassoon, Siegfried

Scholefield, Guy H (Hardy)*

Schwartz, Delmore

Scott, Evelyn

Shepard, Odell ${ }^{* *}$

Sitwell, Dame Edith

Smith, Lillian (Eugenia)*

Smith, Cordwainer

Smith, Edward Elmer

Spicer, Jack** 
Gibson, WW (Wilfrid Wilson)

Gilmore, Dame Mary*

Glassop, Lawson*

Gold, Michael*

Gollancz, Sir Victor*

Graham, Gwethalyn

Green, HM (Henry Mackenzie)*

Groulx, Lionel-Adolphe**

Guthrie, Woody (Woodrow Wilson)

Gye, Hal*

Hackett, Patricia*

Hagedorn, Hermann*

Hamilton, Patrick

Hansberry, Lorraine

Harney, Bill*

Harrington, Edward Phillip*

Harvey, Jean-Charles**

Hecht, Ben

Hesse, Hermann

Hocking, William Ernest

Hodgson, Ralph*

Holbrook, Stewart H (Hall)

Hopegood, Peter*

Hughes, (James) Langston

Hunter, Dard*

Hurley, Frank**

Huxley, Aldous Leonard

Jackson, Shirley (Hardie)

Jarrell, Randall*

Jeffers, (John) Robinson*

Jones, T (Thomas) Harri*
Stefánsson, Vilhjálmur

Stephensen, PR (Percy Reginald)*

Stonehouse, Ethel*

Tanizaki, Junichiro**

Tessimond, ASJ (Arthur Seymour John)**

Texidor, Greville*

Tillich, Paul (Johannes Oskar)

Toklas, Alice B (Babette)

Tolson, Melvin B (Beaunorus)**

Tombs, Harry H (Hugo)*

Toomer, Jean

Treece, Henry

Trevelyan, GM (George Macaulay)

Tritton, Harold Percival Croydon ('Duke')*

Unaipon, David*

Upfield, Arthur

Van Vechten, Carl

Viereck, George Sylvester

Vinal, Harold*

Vittorini, Elio**

Vorse, Mary (Marvin) Heaton*

Waddell, Helen Jane*

Waley, Arthur

Wall, Arnold*

Wallant, Edward Lewis

Watkins, Vernon*

Waugh, Evelyn

Webb, Alice*

Webb, Walter Prescott

White, TH (Terence Hanbury)

Whiting, John* 
Kavanagh, Patrick

Kelland, Clarence Budington*

Kitchin, Clifford Henry Benn

Kreymborg, Alfred*

La Farge, Oliver (Hazard Perry)
Williams, William Carlos

Wilson, Frank Percy*

Wright, Sydney Fowler

$\mathrm{X}$, Malcolm**

Young, Stark 